\title{
Advancements in Thermal Energy Storage System by Applications of Nanofluid Based Solar Collector: A Review
}

\author{
Vednath P. KALBANDE ${ }^{1 *}$, Pramod V. WALKE ${ }^{2}$, C. V. M. KRIPLANI ${ }^{3}$ \\ ${ }^{1-3}$ Department of Mechanical Engineering, G H Raisoni College of Engineering, Nagpur, 440016, India
}

\begin{abstract}
In the recent years, a lot of research has been carried out in the field of nanofluid based solar collector, leading towards the enhancement of working efficiency even at low atmospheric temperature or at low sunlight levels regions of the world. The present review pertains to the research progress related to the performance execution of solar collector using nanofluid. It is observed that the thermal energy storage system (TES), using solar collector, is a useful device for storing sensible and latent heat in a unit volume. Nanofluid plays an important role in various thermal applications such as heat exchanger, solar power generation, automotive industries, electronic cooling system, etc. The nanoparticles find the use in various industrial applications because of its properties, such as thermal, mechanical, optical and electrical. Most of the investigations carried out earlier on the applications of nanofluid in solar energy are related to their uses in the solar collector and thermal storage system. The parabolic solar collector using nanofluid is still a challenge. This article presents an exhaustive review of thermal storage system using nanofluid based solar collector and a scope of using nanofluid based solar collector for performance enhancement.
\end{abstract}

Keywords - Energy Storage; Nanofluid; Phase change material; Solar collector.

\begin{tabular}{|lll|}
\hline Nomenclature & & \\
$C_{p}$ & Specific heat of the substance & $\mathrm{J} / \mathrm{kg} \mathrm{K}$ \\
$F$ & Latent heat of evaporation or fusion & $\mathrm{J} / \mathrm{kg}$ \\
$h$ & Convective heat transfer coefficient & $\mathrm{W} / \mathrm{m}^{2} \mathrm{~K}$ \\
$k$ & Thermal conductivity & $\mathrm{W} / \mathrm{m} \mathrm{K}$ \\
$L$ & Length of tube & $\mathrm{m}$ \\
$D \mathrm{i}$ & Inner diameter of tube & $\mathrm{m}$ \\
$M$ & Mass of the PCM material that undergoes a phase change & $\mathrm{kg}$ \\
$m$ & Mass of medium in which energy is to be stored & $\mathrm{kg}$ \\
$Q_{s}$ & Heat energy stored & $\mathrm{J}$ \\
$T$ & Temperature & ${ }^{\circ} \mathrm{C}$ \\
$u$ & Free stream velocity & $\mathrm{m} / \mathrm{s}$ \\
$\beta$ & Coefficient of thermal expansion & $\mathrm{K}-1$ \\
$\rho$ & Density & $\mathrm{Kg} / \mathrm{m}^{3}$ \\
$\mu$ & Absolute viscosity & $\mathrm{N}-\mathrm{s} / \mathrm{m}^{2}$ \\
\hline
\end{tabular}

* Corresponding author.

E-mail address: vednathkalbande@gmail.com

(C)2020 Vendath P. Kalbande, Pramod V. Walke, C. V. M. Kriplani.

This is an open access article licensed under the Creative Commons Attribution License (http://creativecommons.org/ 


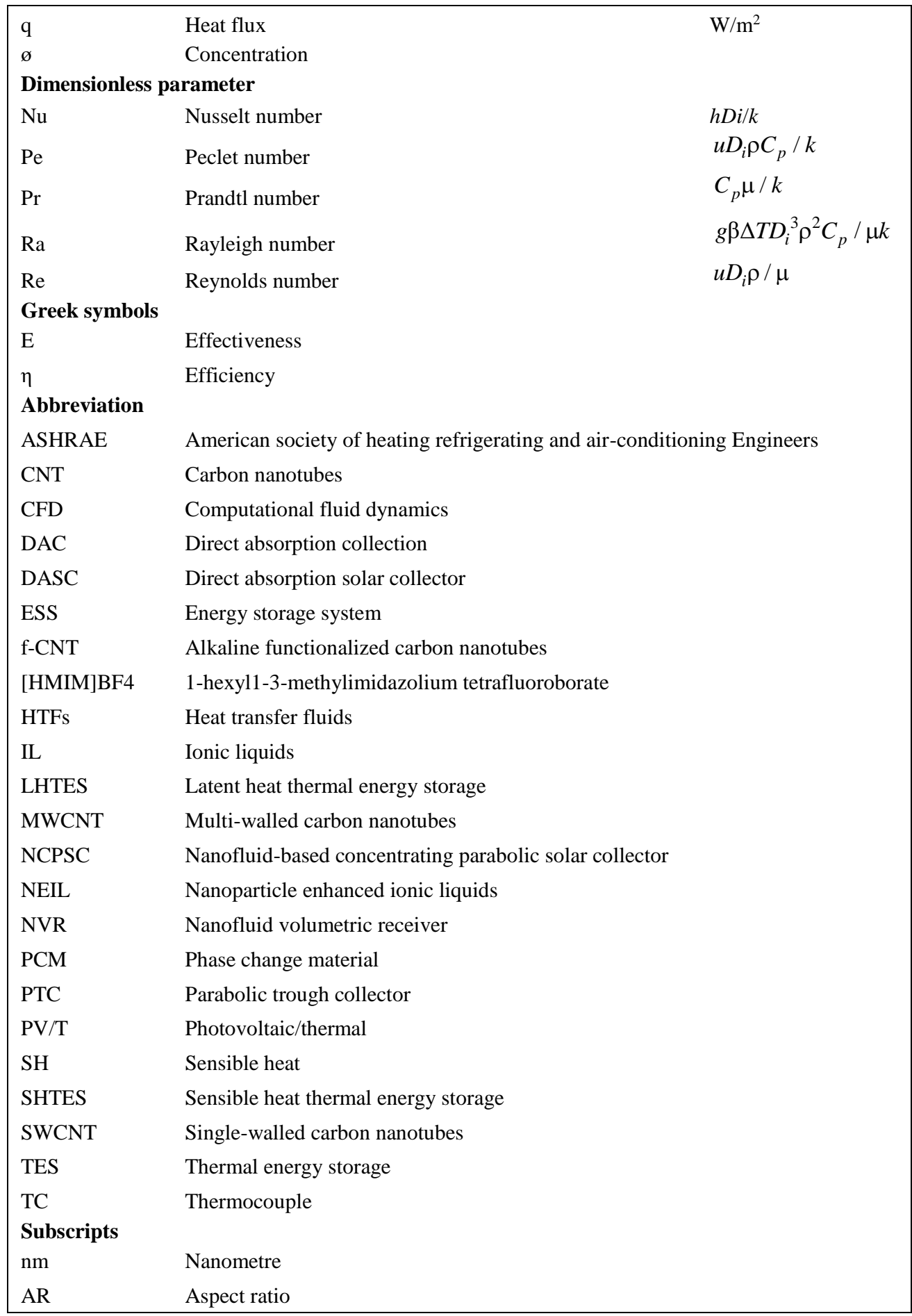




\section{INTRODUCTION}

Solar energy is the most populous form of energy due to its green and environmentally friendly nature. Using solar energy, thermal energy storage can be charged, which is coupled with solar collectors. Preferably, the concentrating and non-concentrating solar collector are mostly used by the researcher. The nanofluid as a heat transfer fluid (HTF) is used to transfer heat from solar collector to thermal storage. Nanofluid is used in solar system to improve the performance. Researchers were taking efforts for solar based thermal storage system which is the cheapest, and easy to construct and design.

The solar energy device efficiency can be enhanced by introducing nanofluid in it [1]. It has been observed from comprehensive study that the replacement of conventional fluid with nanofluid enhances the efficiency of solar collector. The efficiency of the direct solar collector is significantly improved by using nanofluid as a working medium [2]. Nanofluid is a fluid containing a uniform suspension of very small particles having a size in nanometres. Nanofluids have one basic heat transfer fluid which is called base fluid, the nano-sized particles or tubes are then added in proportion into these base fluids. Also, by using a low temperature process, it is seen that this technology can reduce manufacturing costs of the whole system [3], [4]. However, there is a need to determine the effectiveness of thermal energy storage system for integration with solar collector gadgets. A lot of investigations have been reported on phase change materials (PCM) for the latent heat storage system to analyse thermal physical properties for selection criteria, classifications and potential of PCM [5]. For various industrial applications the use of nanofluid is more attracting for cooling. The nanofluids improve the heat transfer rate, thermal properties, optical properties, efficiency, extinction coefficients and transmission of solar systems as compared to conventional fluids [6]. The solar collector efficiency using Cu-water $(25 \mathrm{~nm}, 0.1$ $\mathrm{wt} \%$ ) nanofluids increased by $23.83 \%$, but decreases while using nanofluid of $\mathrm{Cu}$-water $(25 \mathrm{~nm}$, $0.2 \mathrm{wt} \%$ ) as an engrossing medium. As nanoparticle size is increased; the solar collector efficiency will be decreases [7]. Said et al. [8] investigated the effect of $\mathrm{TiO}_{2}$ nanofluid and polyethylene glycol on flat plate solar collector. They varied mass flow rate in the range of 0.0083 to $0.025 \mathrm{~kg} / \mathrm{s}$, and recorded $76.6 \%$ increase in efficiency for $0.1 \%$ volume fraction and $0.0083 \mathrm{~kg} / \mathrm{sec}$ flow rate.

The flat plate collector efficiency, can be enhanced by using Alumina- water based nanofluid, as working fluid. The experimental investigation using $\mathrm{Al}_{2} \mathrm{O}_{3} /$ water nanofluid showed that efficiency of flat plate solar collector increased up to $28.3 \%$ by using $0.2 \mathrm{wt} \%$ nanofluid as absorption medium as compared with water [9]. The four types of receivers were compared to analyse the thermal characteristic properties of the solar collector. The receivers were steel tube with black painted vacuum and black chrome covering with glass enveloped evacuated copper tube [10]. The efficiency of the nanofluid based volumetric receiver (NVR) has been considered on the key engineering parameters, for example, the concentration of nanoparticles, the Nusselt number and Peclet number of heat transfer, and aspect ratio [11]. A numerical analysis of the mixed convection boundary layer flow of a nanofluid along a slanted plate implanted in a permeable medium was carried out with incompressible nanofluid flow [12]. From the above discussion on the nanofluid based solar system can be started from the basic information of nanofluid which is discussed in the following sections.

\subsection{Nanofluids}

Nanofluid is a suspension of nano-sized particles in the base fluid which exhibit the enhanced thermal conductivities than the conventional fluid (base fluid) such as water, 
ethylene glycol and oil [13], [14]. Nanofluids have potential to enhance the properties such as thermal conductivity, viscosity, surface tension, etc., for various applications such as energy, chemical, thermal engineering, electronic, material, environmental, biopharmaceutical, industrial, and medical [15].

The term nanofluid is first given by Choi et al. [14], [16], [17] to describe the suspension of nano-sized (1 to $100 \mathrm{~nm}$ ) solid particles in ethylene glycol and water for stability of nanoparticles. The base fluid properties can be enhanced by dispersion of nanoparticles in it. Thermal conductivity of nanoparticles is mainly responsible for improving the properties of nanofluid. Experimental results in the past report that nanofluid demonstrate essentially higher thermal properties, particularly, thermal conductivity even when suspended nanoparticles concentrations are very low [13], [14], [16]-[19]. The properties details of nanoparticles and base fluid are shown in table 1.

Table 1. Details of Different Nanoparticles and Base Fluid Properties [20]-[29]

\begin{tabular}{llll}
\hline $\begin{array}{l}\text { Name of nanoparticles and base } \\
\text { fluid/formula }\end{array}$ & $\begin{array}{l}\text { Specific heat, } \mathbf{C p} \text { in } \\
\mathbf{k J} / \mathbf{k g ~ K}\end{array}$ & Density, $\boldsymbol{\rho}$ in $\mathbf{k g} / \mathbf{m}^{\mathbf{3}}$ & $\begin{array}{l}\text { Thermal conductivity, } \mathbf{k} \\
\text { in W/m-K }\end{array}$ \\
\hline Alumina/ $\mathrm{Al}_{2} \mathrm{O}_{3}$ [20], [26] & 0.773 & 3958 & 40 \\
Copper Oxide/CuO [20], [26] & 0.553 & 6000 & 33 \\
Titanium di Oxide/TiO ${ }_{2}$ [20], [26] & 0.688 & 4228 & 8.400 \\
Silicon di Oxide/SiO ${ }_{2}$ [21], [26] & 0.765 & 3968 & 36 \\
Silver/Ag [20], [27] & 0.235 & 10485 & 428 \\
Ferro/Fe $\mathrm{O}_{4}$ [28] & 0.670 & 5180 & 9.700 \\
Graphene [29] & 0.708 & 2098 & 5000 \\
Carbon nanotubes [22], [24] & 0.738 & 1352 & 3000 \\
Graphite [20], [24] & 0.702 & 2157 & 120 \\
Ethylene Glycol/EG [28] & 2.415 & 1115 & 0.252 \\
Methanol/methl [28] & 2.547 & 794 & 0.204 \\
Water $\left(\mathrm{H}_{2} \mathrm{O}\right)$ base fluid [26], [27] & 4.184 & 996 & 0.600 \\
\hline
\end{tabular}

Applications of nanofluids can be found in engine cooling, engine transmission oil, solar water heating, thermal storage, refrigeration (domestic and chillers), cooling of electronic circuits, defense and space application, nuclear system cooling, bio-medical application, drilling and lubrication and many such applications [1], [4], [30]-[32].

Nanofluid properties, preparations, nanomaterial, base fluid, nanoparticle volume, and size and heat transfer enhancement are discussed below.

\subsubsection{Properties of Nanofluid and its Preparation}

Properties of nanofluid and its preparation are both dependent parameters. Nanofluid can be prepared with the help of ultra-sonication methods. The concentration ratio of nanoparticles, particles size and shape play an important role in this regard. Authors thoroughly discussed the properties of nanofluid such as viscosity, surface tension, thermal conductivity, etc. with its applications. Research on thermal conductivity of nanofluid has to be further investigated [1], [31], [33]-[37]. 
The Yang et al. [38] reported elaborative preparation of nanofluid, which is schematically shown in Fig. 1.

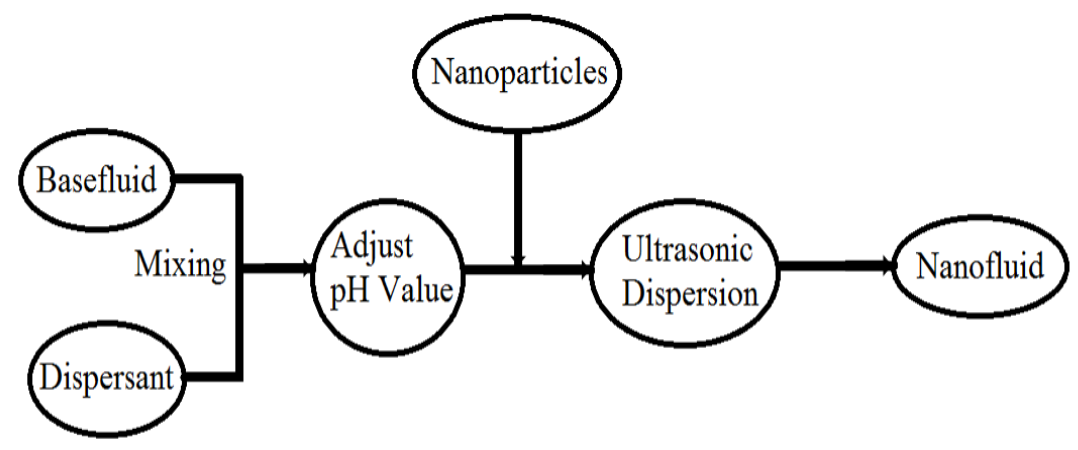

Fig. 1. Diagram of nanofluid preparation flow chart [38].

\subsubsection{Nanoparticle Material and Base Fluid}

The nanoparticles such as $\mathrm{Al}_{2} \mathrm{O}_{3}, \mathrm{TiO}_{2}, \mathrm{CuO}, \mathrm{SiO}_{2}, \mathrm{Au}, \mathrm{Ag}, \mathrm{Fe}$, and $\mathrm{Cu}$ are frequently used in nanofluid preparation; and carbon nanotubes, graphite, grapheme, etc. are used in nanofluid research. Table 1 shows various materials that can be used in nanofluids preparation. The nanoparticles are suspended in common working base fluids (water, engine oil, ethylene glycol, etc.) for heat transfer applications. The additives with small amount are added in the nanofluid mixture to improve nanoparticle stability in the base fluid.

\subsubsection{Nanoparticle Volume Fraction, Size and Shape}

Literature on the suspension of nanoparticles in the base fluid is available. The effect on thermal conductivity of nanofluid due to volume fraction and volume concentration was studied. The qualitative results are usually accounted by many experimental studies to show the effect of volume fraction of nanoparticles with a wide range of base fluid on heat transfer system. The linear relation was found in between thermal conductivity and volume fraction of nanoparticles. The higher volume fraction increases viscosity and it will cause for the higher pumping power requirement due to large shear stresses of nanoparticles. Another important parameter to enhance the properties such as thermal conductivity, viscosity, surface tension, etc. is the nanoparticles size and shape. Researchers mostly prefer $10 \mathrm{~nm}$ to $100 \mathrm{~nm}$ diameter sizes of nanoparticles to prepare nanofluid for the experimental and numerical investigations. The viscosity of smaller diameter nanoparticles is better. Nanoparticles of tiny size increases micro-convection level of heat transfer [3], [17], [46]-[53], [26], [39]-[45].

\subsubsection{Heat Transfer Enhancement with Nanofluids}

The efficiency of the heat transfer system improves by increasing the thermal conductivity of nanofluid. Forced convection is considered in tube for heat transfer process. While natural convection is considered in the cylinder for the analysis of heat transfer with nanofluid. According to the definition of dimensionless number, the thermal conductivity enhancement obtained by using nanofluid is equal to the enhancement in heat transfer coefficient of the nanofluid, which is expected. The experimental and numerical studies about the convective 
heat transfer of nanofluid shows that the enhancement in thermal conductivity of nanofluid is obtained due to heat transfer coefficient enhancement of nanofluid. Heat transfer coefficient was enhanced with higher rate in developed region of tube flow. The heat transfer through convection is more dominant in the thermal system where working fluid is nanofluid [3], [54], [63]-[70], [55]-[62].

Suspension is made with the help of magnetic stirring or ultrasonic stirring in the base fluid, the nanoparticles used may either be metallic or non-metallic. Nanoparticles aggregation forms large size particles which will create clustering. Clustering of nanoparticles exhibit the enhancement in thermal conductivity of nanofluid [41], [71]. Nanoparticles enhance optical properties of base fluid and improve the absorption properties of flat plate solar collector [39], [72]. The forced convection and thermophysical study of alumina-menthol was carried out and it was found that the heat capacity enhanced by $50 \%$ at nanoparticles volume concentration of $0.05 \%$ [73]. The optical properties are enhanced by nanoparticles with lesser concentrations in water and glycol base fluids, and nanofluids can be used for low temperature applications, on other had for high temperature application there is the need of oil based nanofluids which are suitable for up to $300{ }^{\circ} \mathrm{C}$ [74], [75]. Arshad et al. [76] experimentally investigated the hydrodynamic and thermal performance of graphene based nanofluid. It is found that the convective heat transfer enhanced by $13.6 \%, 15.38 \%$ and $21.51 \%$ at heat flux of $71.94 \mathrm{~kW} / \mathrm{m}^{2}, 59.95 \mathrm{~kW} / \mathrm{m}^{2}$ and $47.96 \mathrm{~kW} / \mathrm{m}^{2}$, respectively. Saidur et al. [39] have investigated potential use of $\mathrm{Al}_{2} \mathrm{O}_{3}$ nanoparticles in direct absorption type solar collectors. They found that $\mathrm{Al}_{2} \mathrm{O}_{3}$ has improved the absorption when used in concentration up to $1 \%$ in volume fraction. Also they concluded that for direct solar collector the use of nanofluids as volumetric absorber shows excellent improvement in thermal properties and it can be a good solution for direct solar collector. Qiao et al. [77] found that evaporation rate of MWCNT nanofluid is higher than pure ethanol by $25.6 \%$ and is also higher than carbon nanoparticles or Al nanofluid by $18.7 \%$. Faizal et al. [26], [40] have concluded that with the use of aluminum oxide nanoparticles as absorbing medium the size of the collector can be reduced up to $24 \%$. Also the aluminum oxide is cheaper as compared to other nanoparticles which makes it ideal for this application.

\subsection{Thermal Energy Storage}

The thermal energy system principle is applicable for all the systems. The energy can be removed or used later from thermal storage system. Thermal storage can be categorized in two crucial groups: sensible heat thermal storage (SHTES) and latent heat thermal storage (LHTES) [78].

\subsubsection{Sensible Heat Storage}

Sensible heat $(\mathrm{SH})$ is the heat related with an adjustment in temperature of a solid or liquid. The heat energy $\left(Q_{s}\right)$ stored in such solid or liquid is given by the Eq. (1):

$$
Q_{s}=\left(T_{2}-T_{1}\right) \cdot C_{p} \cdot m,
$$

where

$Q_{s} \quad$ heat energy stored, $\mathrm{J}$;

$\mathrm{m}$ mass of medium in which energy is to be stored, $\mathrm{kg}$;

$C_{p} \quad$ specific heat of the substance, $\mathrm{J} / \mathrm{kg} \cdot \mathrm{K}$;

$T_{1}$ and $T_{2}$ are the initial and final temperature, respectively, ${ }^{\circ} \mathrm{C}$. 


\subsubsection{Latent Heat Storage}

Latent heat $(\mathrm{LH})$ is the heat retained or freed by a phase change or transition and it occurs when the temperature is constant. The latent heat $\left(\mathrm{Q}_{\mathrm{s}}\right)$ through a change of phase is given by the Eq. (2):

$$
Q_{s}=M \cdot F,
$$

where

$Q_{s} \quad$ storage energy, $\mathrm{J}$;

$M \quad$ mass of the PCM material that undergoes a phase change, $\mathrm{kg}$;

$F \quad$ is the latent heat of evaporation or fusion, $\mathrm{J} / \mathrm{kg}$.

\subsection{Phase Change Material for Thermal Energy Storage with Nanofluid}

A phase change material (PCM) is used in a thermal storage system due to its high heat of fusion. It can store the heat while melting and releasing it during solidification. The material changes its phase from solid to liquid and vice versa, when it is absorbed or released the heat. PCM is the latent thermal storage material. The phase change materials are substances to store and discharge the heat, due to which transfer of thermal energy occurs when a material changes from solid to liquid and vice versa. Advantages of phase change system are a high storage capacity, the phase change of the storage material proceed at an almost constant temperature, and a high density [79]-[82]. The phase change material is divided into three basic types i.e. organic, inorganic and eutectic. Further organic phase change material is divided into paraffin and non-paraffin compound. The inorganic phase change material is divided into salt hydrate and metallic. Eutectic phase change material is divided into organic-organic, inorganic-inorganic and inorganic-organic [83].

Thermal storage coupled with solar collector using nanofluid as a HTF is the better option to store energy in thermal energy storage. The nanofluid plays key role in the enhancement of efficiency of the solar based thermal storage system. As discussed in section 1.1.4, as heat transfer rate of nanofluid increases, it will improve the performance of solar collector to store energy in thermal energy storages. The $\mathrm{TiO}_{2}+$ water nanofluid as HTF was used in solar heat exchanger. The average heat transfer coefficient increases by $21 \%$ due to use of $\mathrm{TiO}_{2} / \mathrm{water}$ nanofluid [84]. The ionic-liquid and molten-salt based nanofluid was studied for thermal storage system to improve its performance. Molten salts properties such as specific heat, thermal conductivity etc. have been studied with higher range of temperature using nanofluid as a HTFs [85].

The detailed study regarding thermal storage systems using concentrated and non-concentrated solar collector is given in sections 2,3 and 5.

The thermal storages are basically coupled with solar collector. The solar collector using nanofluid as a working fluid transfer energy to thermal storage. So, the various types of solar collector that can be useful for the thermal storage system is discussed in the following section.

\subsection{Solar Concentrating Systems}

Mirrors or lenses are used in concentrated solar power systems to concentrate a whole incident sunlight or solar thermal energy, into a small area to generate solar power. The concentrating type solar collector having operating temperature range is maximum [86]. Nanofluid for the thermal storage system is basically operated at higher temperature. So these category of solar collector is best suitable for the thermal storage system using nanofluid as 
HTF [87]. There are different types of solar collector and they are described in the next sections.

\subsubsection{Parabolic Trough System}

The linear parabolic reflector in parabolic trough system concentrates light on receiver along the reflector focal line. The working fluid is filled with a tube which is situated directly above the centre of the parabolic mirror of receiver [88]. Working fluid in receiver is utilised as a heat source for a power generation system and can be heated up to $150-350{ }^{\circ} \mathrm{C}$. The concentrated solar power with trough systems are the most developed technology.

\subsubsection{Parabolic Dish}

Solar energy concentrates on a single focal point by using one or more parabolic dish in parabolic dish collector such as the way reflecting telescope focuses starlight. For the solar furnaces and solar power plant, this type of collector may be used. The incoming light rays are reflected towards the focus due to parabolic shape and rays parallel to the dish's axis.

The incident ray of light from the sun to earth is almost parallel. So, all incoming rays of the sun reflected towards the focal point of the dish due to the fact that the dish is aligned with its axis at the sun.

\subsubsection{Power Tower}

A power tower is a tracking mirrors called heliostats are surrounded on a large tower. At the top of the tower of receiver sunlight is focused by tracking mirrors. The optical fiber cable can be used as illuminating buildings for redirecting concentrated light to a suitable location.

During cloudy and overnight conditions, the heat storage is accomplished for power production by the underground tank storage of heated fluids. The liquid metals can be proposed as the working fluid due to superior thermal properties. To maintain sunlight focus at the collector, the sun tracking is required for concentrating system. The diffused light cannot be concentrated; therefore, concentrating system drops drastically in cloudy condition.

\subsubsection{Stationary Concentrating Collector}

The compound parabolic reflectors and flat reflectors are used in the stationary concentrating collector for directing solar energy to an absorber or aperture through a wide acceptance angle. There is no need of sun tracker, due to the wide acceptance angle in reflectors. In this category parabolic trough flat plate solar collectors, flat plate solar collectors with parabolic boosting reflectors and solar cooker are include. These solar collector with nanofluid was used by researcher to enhance the performance of solar based system. Stationary collector with nanofluid as working fluid is easy to handle.

\section{Nanofluid BaSed Thermal Storage System with Solar Collector}

The thermal properties of nanofluid for various applications can be achieved at small concentration and with stable suspension and homogeneous dispersion of nanoparticles in the base fluid. Energy saving and operational temperature in solar collector is affected due to the 
heat transfer augmentation. Nanofluids can satisfy the specific needs and constraints if heat transfer increases in solar thermal based system [1].

The physical and thermal properties of host fluid can be improved by suspending of nanoparticles into a liquid. The efficiency and performance of solar collector can be improved by decreasing energy losses and increasing energy transfer. The energy losses can be reduced by glazing and washing the absorber and improving sun radiation reflection. Suspension of nanoparticles will result into enhancement of the optical properties of base fluid. Suspended nanoparticle of very small diameter has a higher extinction coefficient in nanofluid when contrasted with ordinary base fluid. The extinction coefficient is obtained about $17 \cdot 10^{5}$ at a diameter of $20 \mathrm{~nm}$ [39]. In this way, it is more competent to absorb the energy from incident sunlight in a solar collector [2].

To enhance the efficiency of the solar system nanofluid can be used, but the efficiency does not always enhance by a higher solid volume fraction. For solar collector efficiency it is needed to study the effect of nanoparticle size. Nanofluid research is essential for development of particle production and decreasing in cost [3]. The nanoparticles to enhanced efficiency of the system is discussed below.

\subsection{Nanoparticles for Thermal Storage System Using Solar Collector}

The phase change materials for latent heat storage system using nanofluid as working medium is much more effective method to store the solar energy through a solar collector. Phase change materials (PCM) are for the most part favoured because of the wide range of temperature, congruent melting and high latent heat, but these PCMs have low transfer of heat and low thermal conductivity. It is observed that the metals, metal oxides and carbon-based nanomaterial such as $\mathrm{Ag}, \mathrm{Cu}, \mathrm{Al}, \mathrm{Al}_{2} \mathrm{O}_{3}, \mathrm{MgO}, \mathrm{CuO}, \mathrm{ZnO}, \mathrm{TiO}_{2}$, expanded graphene nanosheets, graphite sheets, MWCNT, SWCNT, active carbon, graphene flakes, nanofibers all these are incorporated with phase change materials to get efficient phase change properties [5]. Solar system with nanofluid is having many challenges to use, such as instability and agglomeration problem, high cost of production, erosion and increased pumping power. This can be reduced with further research in nanoscience [4].

The nanoparticle suspension in conventional fluid is resulting into a new generation of heat transfer fluid. The thermal conductivity of suspended nanoparticles in nanofluid has substantially higher than host fluid. Nanofluids have good forced and natural convective heat transfer properties as compared to base fluid due to suspension of nanoparticles [6].

The thermal solar collector has been developed using new configurations for the solar water collector on residential building for the experimental findings. The absorber with cold water tube and less insulation is having better performance than the actual prototype [89], [90]. A review was conducted for CFD analysis on a flat plate solar collector to analyse the thermal storage system. Review summarized that the solar collector design for better performance and less expensive for simplest outdoor test to optimize thermal performance of system [91]. The solar energy stored in the thermal storage system using PCM is the effective methods for the domestic applications. The thermal conductivity and photo-thermal properties show that the nanoparticles have a very good ability to absorb solar energy. The base fluid properties improve by using suspended nanoparticles, which are subject to particle shape, particle size, the optical properties of the particle and base fluid [92], [93]. 


\subsection{Effect of Nanofluid on Solar Collector and Thermal Storage Efficiency}

The nanofluid having nanoparticles absorbed heat from the sun through solar collector and will transfer its heat to thermal storage. Due to the higher thermal conductivity of metallic nanoparticles, the heat transfer rate will be increased. The increasing heat transfer rate increases the efficiency of the system. Absorption of heat from the heat source is increases due to nanoparticles and it transfers heat to thermal storage at higher rate than that of base fluid. Also, the heat in thermal storage increases rapidly due to the effect of nanoparticles. So, the efficiency of solar collector and thermal storage unit is increased by using nanofluid.

\section{Non-Concentrating Solar Collector}

\subsection{Flat Plate Solar Collector}

Kabeel et al. [94] numerically investigated nanofluid based solar collector using the novel integrated system for small scale needs by using the flashing desalination technique. The production of desalted water and the cost of system was estimated. The five parameters which are affecting the cost of system and production were studied. These parameters are nanoparticles volume fraction, cooling water mass flow rate, feed water mass flow rate, feed water salinity and cooling water inlet temperature. The investigation was carried out on flat plate solar collector and the working fluid of copper nanoparticles.

He et al. [7] experimentally carried out efficiency of nanofluid based flat plate solar collector by the addition of copper nanoparticles with different mass fraction in pure water, which is shown in Fig. 2. The addition of nanoparticles to pure water results in increasing thermal conductivity of the base fluid. The size of the nanoparticles affects the efficiency of the system. The temperature and heat gain by water is increased up to $12.24 \%$ and $24.5 \%$, respectively, by using nanofluid $(25 \mathrm{~nm}, 0.1 \mathrm{wt} \%)$ in water. If hot water temperature for application is not achieved, it will recirculate by water pump to the heat exchanger, until desired temperature is achieved.

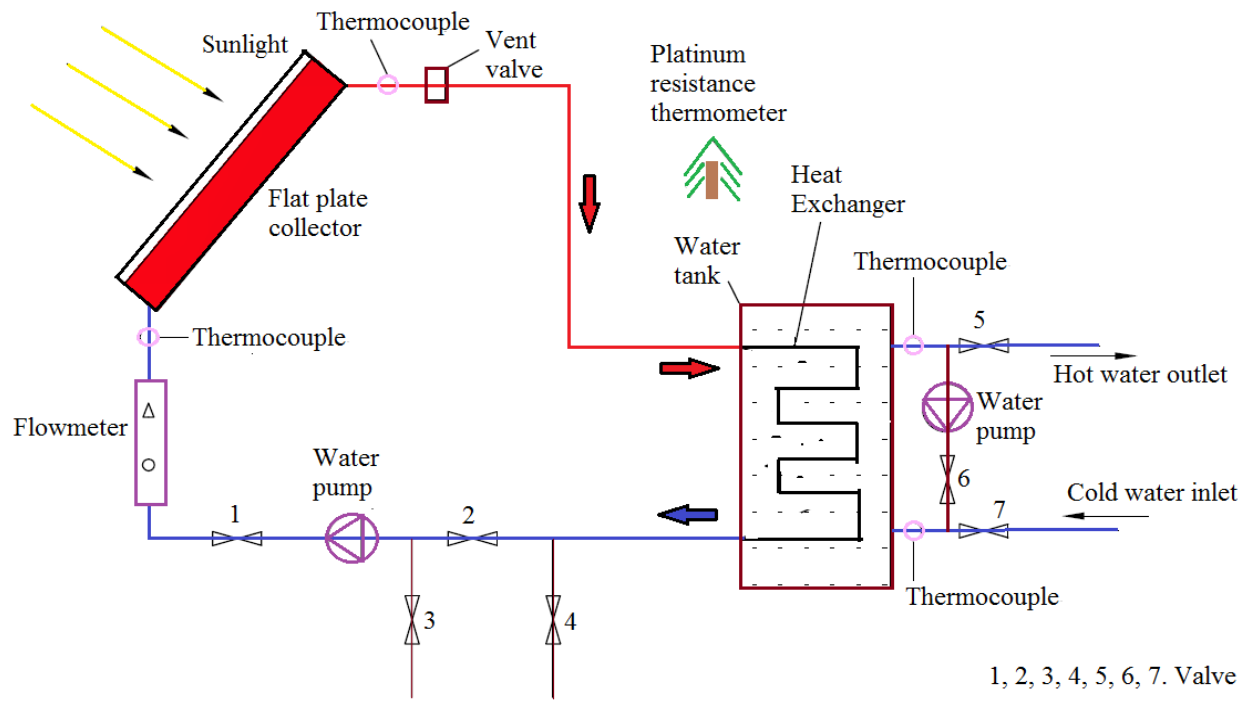

Fig. 2. Experimental setup of solar thermal energy measuring system [7]. 
Said et al. [95] studied pumping power and exergy efficiency of SWCNT based nanofluid for the conventional flat plate collector. The study was compared between two nanofluids, SWCNT and metal oxide $\left(\mathrm{Al}_{2} \mathrm{O}_{3}, \mathrm{TiO}_{2}\right.$ and $\left.\mathrm{SiO}_{2}\right)$ based nanofluid for flat plate collector. The thermal properties and exergy efficiency of SWCNT was found to be better than of the metal oxide nanofluid. Schuchardt et al. [96] experimentally studied the impact on exergy and energy efficiency on centralized and decentralized heat storage systems and it is found to be $82.4 \%$ and $84.2 \%$, respectively. Faizal et al. [26] compared study of different nanofluids for flat plate solar collector on the basis of economic and environmental parameters. The properties of $\mathrm{CuO}$ nanofluid had the highest values as compared to alumina, titanium di-oxide and silicon di-oxide nanofluids. The environmental and economic analysis of different nanofluids is shown in Table 2.

TABle 2. Comparison of DifFEREnT NANOFluid fOR Flat Plate Solar Collector [26]

\begin{tabular}{|c|c|c|c|c|c|c|}
\hline & $\begin{array}{l}\text { Electric } \\
\text { Heater }\end{array}$ & $\begin{array}{l}\text { Solar based } \\
\text { Heater, } \\
\text { water }\end{array}$ & $\begin{array}{l}\text { Solar based } \\
\text { Heater, } \\
\text { Alumina }\end{array}$ & $\begin{array}{l}\text { Solar based } \\
\text { Heater, } \\
\text { Titanium di } \\
\text { Oxide }\end{array}$ & $\begin{array}{l}\text { Solar based } \\
\text { Heater, } \\
\text { Silicon di } \\
\text { Oxide }\end{array}$ & $\begin{array}{l}\text { Solar based } \\
\text { Heater, } \\
\text { Copper } \\
\text { Oxide }\end{array}$ \\
\hline Capital costs, Rs & 6563.68 & & & & & \\
\hline $\begin{array}{l}\text { Independent costs, } \\
\text { Rs }\end{array}$ & & 49227.57 & 49227.57 & 49227.57 & 49227.57 & 49227.57 \\
\hline $\begin{array}{l}\text { Area based costs, } \\
\text { Rs }\end{array}$ & & 16409.19 & 12873.83 & 12776.03 & 12871.04 & 12208.77 \\
\hline $\begin{array}{l}\text { Nanoparticles cost, } \\
\text { Rs }\end{array}$ & & & 1804.35 & 1544.60 & 1215.92 & 1924.80 \\
\hline Total cost, Rs & 6563.68 & 65636.76 & 63905.75 & 63548.20 & 63314.53 & 63361.14 \\
\hline $\begin{array}{l}\text { Electricity cost } \\
\text { saving per year, Rs }\end{array}$ & & 26353.16 & 26353.16 & 26353.16 & 26353.16 & 26353.16 \\
\hline $\begin{array}{l}\text { Years of electricity } \\
\text { savings }\end{array}$ & & 2.49 & 2.42 & 2.41 & 2.40 & 2.40 \\
\hline
\end{tabular}

Said et al. [8] carried out a performance using polyethylene glycol dispersant and $\mathrm{TiO}_{2}-\mathrm{H}_{2} \mathrm{O}$ nanofluid in flat plate collector as shown in Fig. 3. The volume fraction with $0.3 \%$ of titanium dioxide is enhancing the thermal conductivity of titanium dioxide-water nanofluid up to $6 \%$. The exergy efficiency, improved by up to $16.9 \%$ for 0.1 vol\% of nanoparticles concentration and $0.0083 \mathrm{~kg} / \mathrm{s}$ of flow rate, while the energy efficiency obtained at $0.1 \mathrm{vol} \%$ and $0.0083 \mathrm{~kg} / \mathrm{s}$ is $76.6 \%$ by using nanofluids instead of water.

Yousefi et al. [9] studied experimentally an alumina-water nanofluid effect on flat plate solar collector efficiency as shown in Fig. 4. The effects of mass fraction of nanoparticles, mass flow rate and surfactant on the efficiency of the solar collector were studied. The nanoparticles weight fraction was $0.2 \%$ and $0.4 \%$ and $15 \mathrm{~nm}$ size nanoparticles were studied. The efficiency was calculated by using ASHRAE standard, where water as the assimilation medium with and without X-100 as a surfactant. 


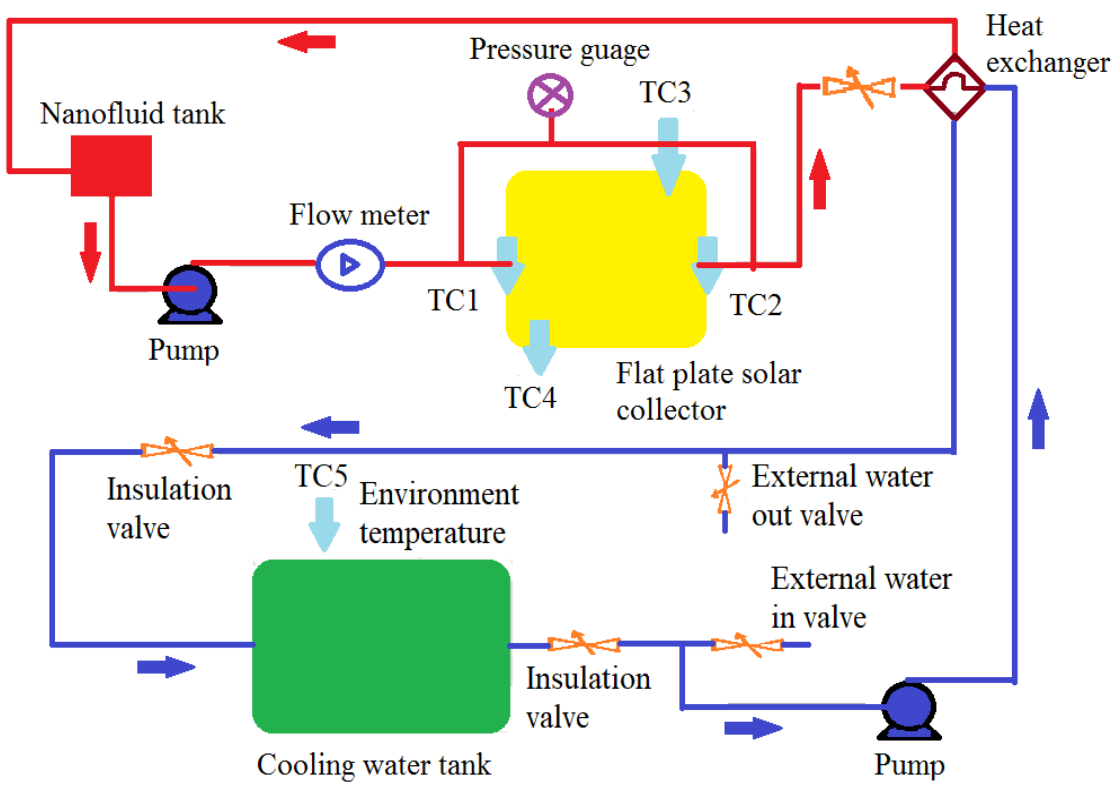

Fig. 3. Detail assembled diagram of solar collector, cooling water tank, and heat exchanger [8].

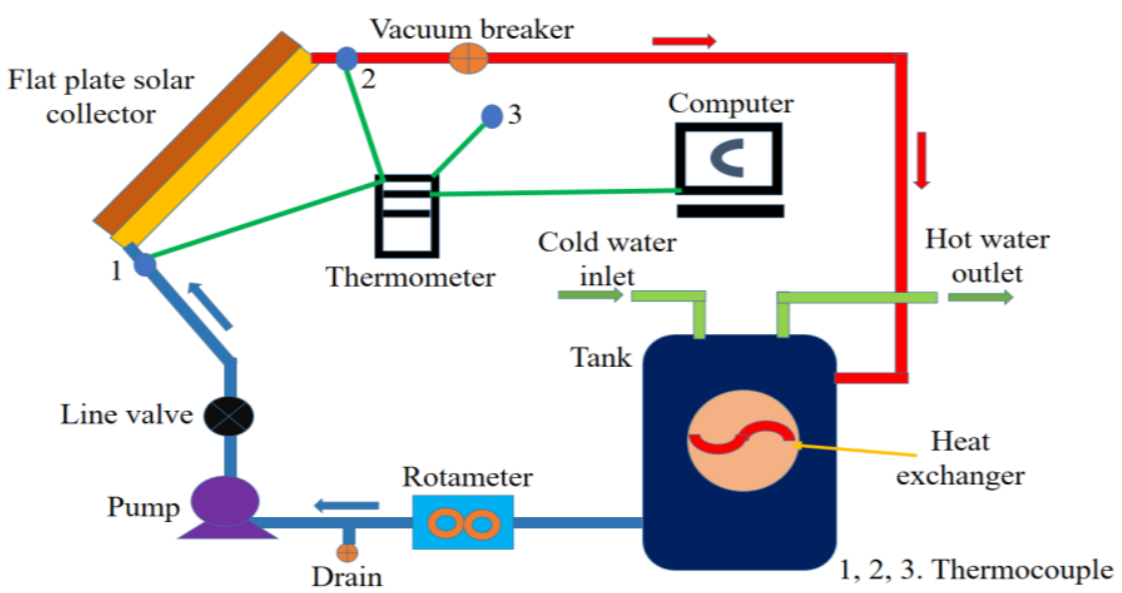

Fig. 4. The detailed schematic diagram of experimentations [9].

Nasrin et al. [97] studied numerically forced convective analysis of semi-empirical relation for a solar collector shown in Fig. 5. The flow, temperature, and heat flux fields as well as average velocity, collector efficiency, mean bulk temperature, heat transfer rate and mid-height temperature of the fluids through the riser pipe has been considered for various Prandtl No. and Reynolds No. values. Al- Kayiem et al. [98] evaluated the performance of integrated solar water heater (shown in Fig. 6) using a PCM nanocomposite for TES at an inclination of $10^{\circ}, 20^{\circ}$ and 
$30^{\circ}$ angles. Three cases (shown in Table 3 ) were investigated, they are without TES material, with phase change material and with nanocomposite. The paraffin wax was a PCM and nanocomposite of $1.0 \mathrm{wt} \%$ of $20 \mathrm{~nm}$ copper nanoparticles and paraffin wax with base material. At $10^{\circ}$ inclinations the system performance was getting optimal.

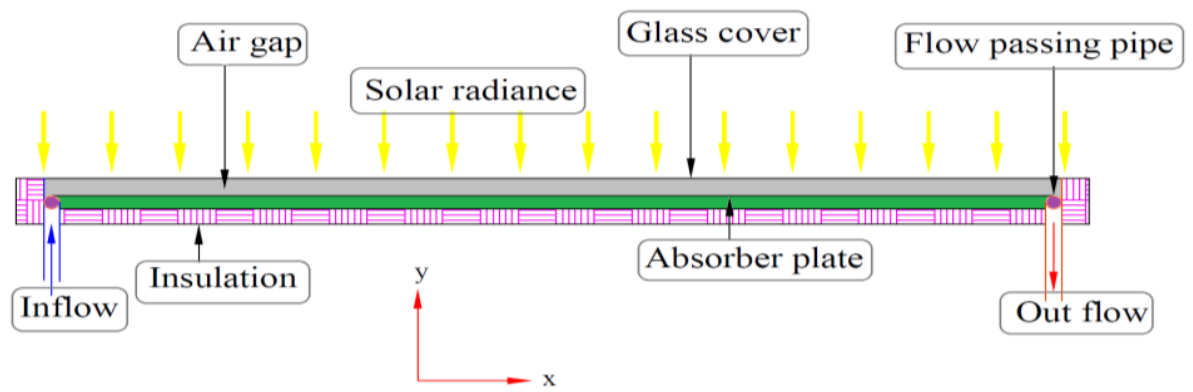

Fig. 5. Schematic diagram of solar collector for forced convection analysis [97].

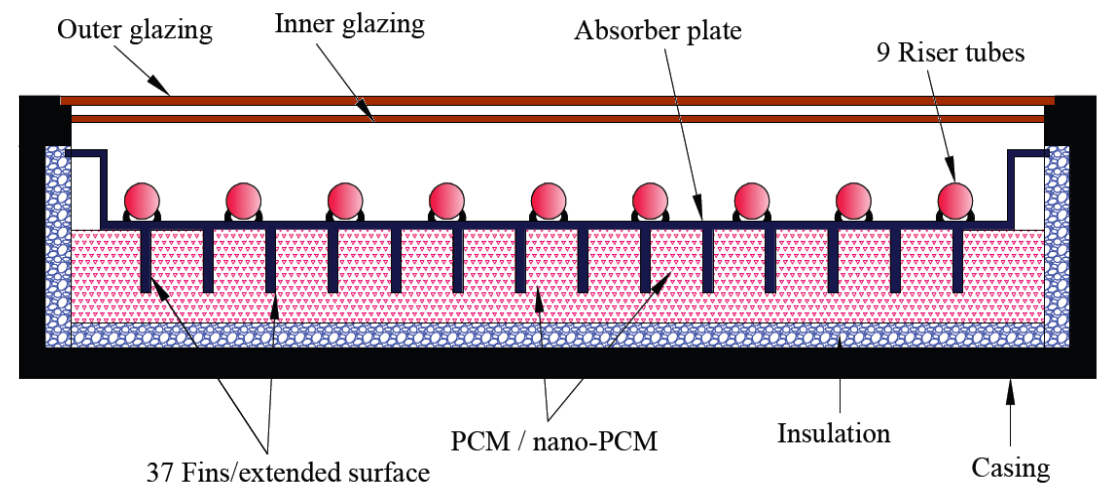

Fig. 6. Schematic view of the solar - thermal energy storage integrated collector [98].

Sekhar et al. [99] experimentally studied the $\mathrm{Al}_{2} \mathrm{O}_{3}+$ water nanofluids heat transfer characteristics enhancement on twisted tapes in a pipe. Prakasam et al. [100] performed experimentally the effects of mass flow rates on flat plate solar water heater using aluminum/water based nanofluid. The flow rates of $\mathrm{Al}_{2} \mathrm{O}_{3} /$ water vary from 1 to $3 \mathrm{lit} / \mathrm{min}$ for lower volume concentration of $0.01 \%$. The performance of flat plate solar water heater system was compared with two working fluid, i.e. distilled water and $\mathrm{Al}_{2} \mathrm{O}_{3}$ /water nanofluid. It was found that the flat plate solar water heater efficiency, enhanced by $14.3 \%$ at the nanofluid flow rate $2 \mathrm{lit} / \mathrm{min}$ and if flow rate increases then the efficiency of collector also decreases.

Dasaien et al. [101] investigated experimentally the enhancement of flat plate solar water heater through thermosyphon system using copper oxide nanofluid. The performance of solar collector was carried out for different mass concentration of nanoparticles and mass flow rates of nanofluid. The efficiency of the collector has been enhanced by $5.7 \%$ at $0.0033 \mathrm{~kg} / \mathrm{s}$ flow rate of $\mathrm{CuO}$ nanofluid. The computational and experimental analysis shows that using $\mathrm{CuO}$ nanofluid can improve the performance of solar collector through thermosyphon system. 
TABLE 3. MEASURED SySTEM EFFICIENCIES ARE AT INCLINATION ANGLES OF 10, 20 AND 30 DEGREES RESPECTIVELY OF OPERATIVE CASES [98]

\begin{tabular}{lllll}
\hline Case & $\begin{array}{l}\text { Max efficiency in } \\
\text { percentage }\end{array}$ & $\begin{array}{l}\text { Percentage of } \\
\text { improvement }\end{array}$ & $\begin{array}{l}\text { Overall efficiency } \\
\text { in percentage }\end{array}$ & $\begin{array}{l}\text { Percentage of } \\
\text { improvement }\end{array}$ \\
\hline $\begin{array}{l}\text { At 10-degree } \\
\text { inclination }\end{array}$ & & & & \\
Case I & 68.8 & - & 47.6 & - \\
Case II & 69.0 & 0.3 & 51.1 & 6.8 \\
Case III & 69.7 & 1.3 & 52.0 & 8.5 \\
\hline $\begin{array}{l}\text { At 20-degree } \\
\text { inclination }\end{array}$ & & & & \\
Case I & 65.8 & - & & - \\
Case II & 66.2 & 0.6 & 44.8 & 5.9 \\
Case III & 66.8 & 1.5 & 47.6 & 6.7 \\
\hline $\begin{array}{l}\text { At 30-degree } \\
\text { inclination }\end{array}$ & & 48.0 & \\
Case I & 56.0 & & & - \\
Case II & 57.0 & - & 37.1 & 4.9 \\
Case III & 58.0 & 1.8 & 39.0 & 6.3 \\
\hline
\end{tabular}

Colangelo et al. [102] studied numerically influence of nanoparticle concentration on the thermal efficiency of solar thermal collector by using water and $\mathrm{Al}_{2} \mathrm{O}_{3}$ nanofluid. The numerical model was developed for the solar thermal collector to study the behaviour of concentration of $\mathrm{Al}_{2} \mathrm{O}_{3}$ nanoparticles

\subsection{Flat Panel and Cover Type Solar Collector}

The efficiency of flat panel solar collector has been enhanced by using Water- $\mathrm{Al}_{2} \mathrm{O}_{3}$ nanofluid. The nanofluid with $1 \mathrm{vol} \%$ to $3 \mathrm{vol} \%$ was prepared to avoid sedimentation in system. Thermal conductivity $(k)$ and heat transfer coefficient $(h)$ were measured by using a hot wire technique as shown in Fig. 7. It was found that at $3 \%$ volume fraction, the efficiency of flat panel solar collector increases by up to $6.7 \%$ [103].

The water- $\mathrm{Al}_{2} \mathrm{O}_{3}$ nanofluid was used in the solar collector and investigated the impact of Prandtl number on natural convection boundary layer flow. Results shows that the heat transfer and fluid flow for various Prandtl number range. From the results it is observed that the isothermal contours get affected considerable by Prandtl number range from 1.73 to 6.62. The heat transfer rate of water-alumina nanofluid was most effective at higher Prandtl number [104].

An optical collocation method was used for the heat transfer analysis of flow over infinite stretching solar plate through two phase nanofluid flow. The effect of stretching rate, nanoparticles concentration, Schmidt number, Prandtl number and Brownian motion parameter has been discussed [105]. 


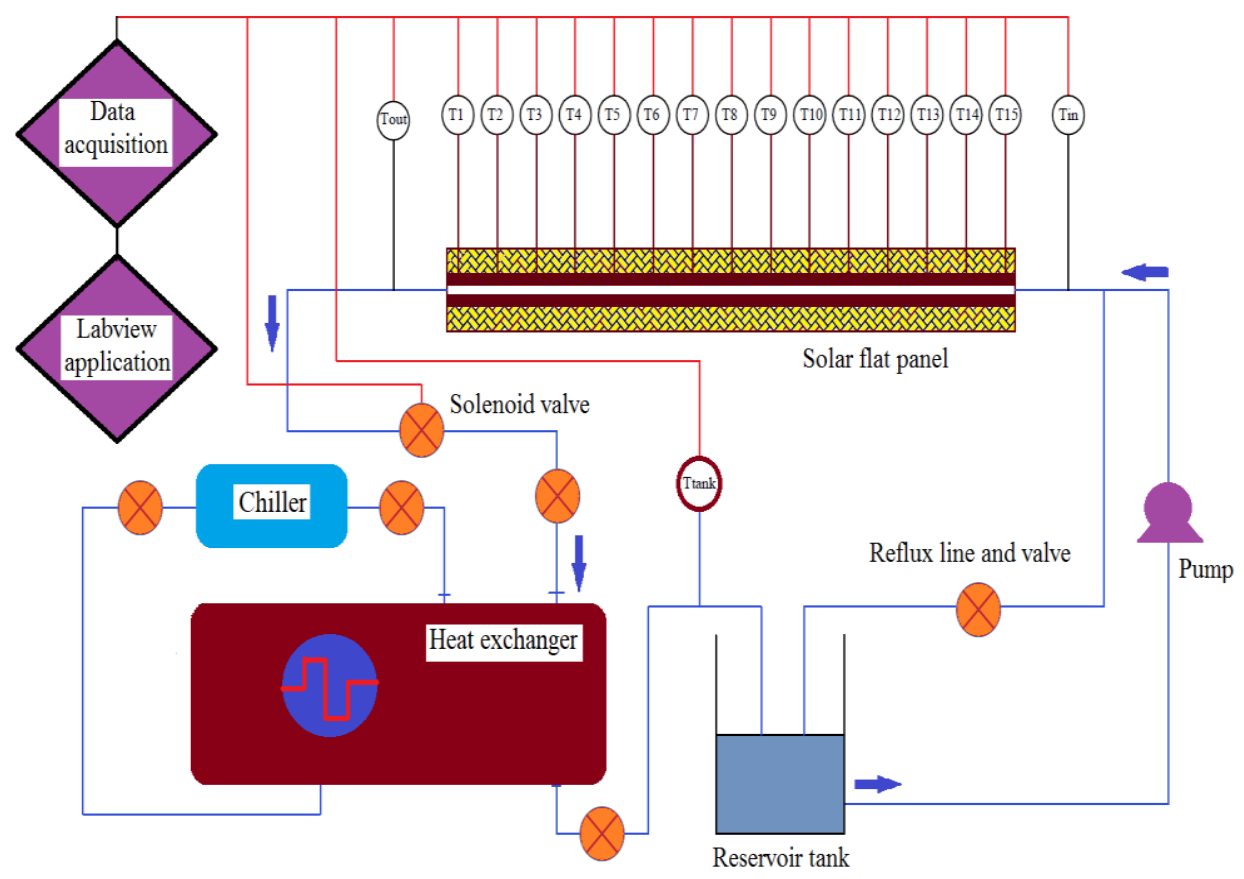

Fig. 7. Experimental setup for the measurement of convective heat transfer coefficient [103].

\subsection{Nanofluid with Non-concentrated Solar Collector for Applications}

The weight fractions of nanoparticles $0.1-0.5 \%$ were used by researcher and the size of the nanoparticles, from $25 \mathrm{~nm}$ to $100 \mathrm{~nm}$ was experimentally studied with non-concentrated solar collector. Non-concentrated solar collector maximum temperature is reached up to the $150{ }^{\circ} \mathrm{C}$ and required sophisticated design to reach this temperature. The efficiency of non-concentrated solar collector using nanofluid is comes up to $25 \%$ or less. To achieve $200{ }^{\circ} \mathrm{C}$ temperature non-concentrated solar collector is replaced with the concentrated solar collector. The nanoparticles weight fractions may vary from $0.1 \%$ to $1 \%$ for the detailed investigations. The nanoparticles size from $25 \mathrm{~nm}$ to $300 \mathrm{~nm}$ can be used for further research. Therefore, it is required to conduct further research to achieve new goals and applications.

Thermal storage unit require temperature higher than $200{ }^{\circ} \mathrm{C}$ temperature to stored energy for cooking, heating, and industrial applications. Concentrated type solar collector with nanofluid is more efficient for the set of above applications.

\section{Direct Absorption Solar Collector}

The direct absorption solar collector system using carbon nanotube as a working fluid for low temperature was investigated experimentally. The thermal conductivity, stable suspension and optical properties of f-CNT are more preferable to use as a working fluid in DASCs. The addition of $150 \mathrm{ppm}$ of f-CNT significantly enhanced the thermal conductivity of the working fluid (water) by up to $32.2 \%$. Also, it increases the extinction coefficient of 
working fluid [106]. The efficiency of DASCs has been investigated on the basis of flow rate of $\mathrm{Al}_{2} \mathrm{O}_{3}-\mathrm{H}_{2} \mathrm{O}$ nanofluid as shown in Fig. 8. The flow rates of nanofluid of 1.5, 2.0, $2.5 \mathrm{lpm}$ were taken for experimentation. The optimum collector efficiency was achieved at a flow rate of 2.0 and $2.5 \mathrm{lpm}$ in this study [107].

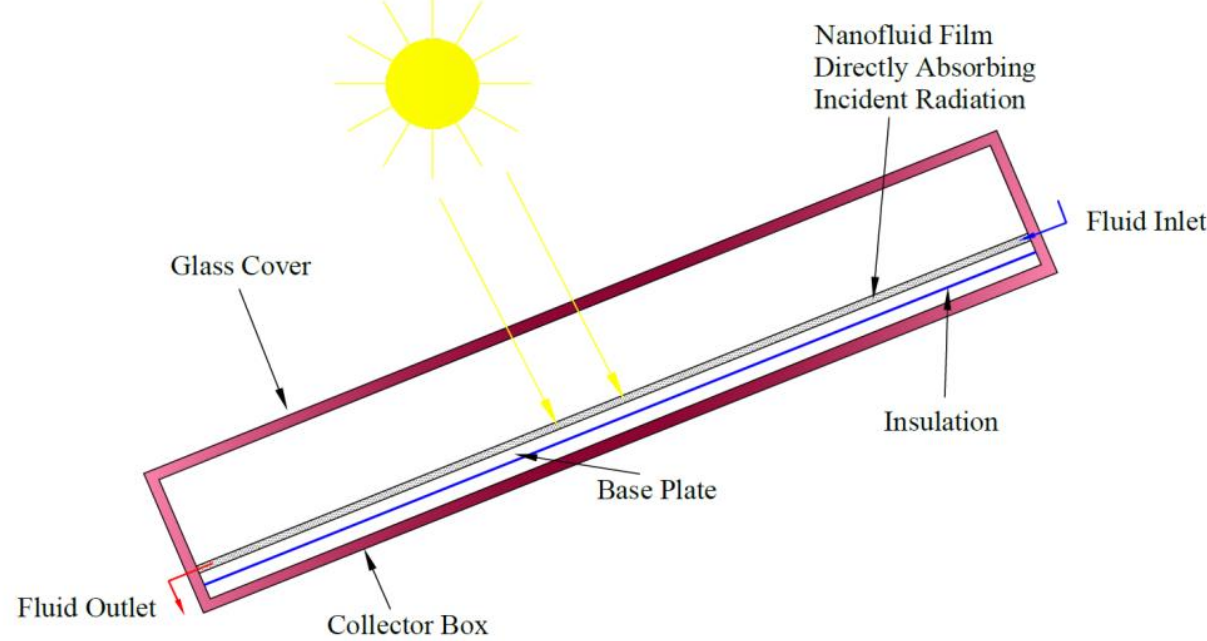

Fig. 8. The schematic diagram of DASCs for experimentation [107].

The direct absorption solar thermal collector using graphene/ionic liquid based nanofluid was experimentally and numerically investigated (see Fig. 9). Graphene concentration regulates the radiative properties of graphene/[HMIM] $\mathrm{BF}_{4}$. The effect on convective heat transfer loss and thermal re-emission due to graphene was investigated by numerical model to predict the temperature profile. Also, graphene water based nanoplatelets was experimentally tested for the fin heat sink [76], [108], [109].

a

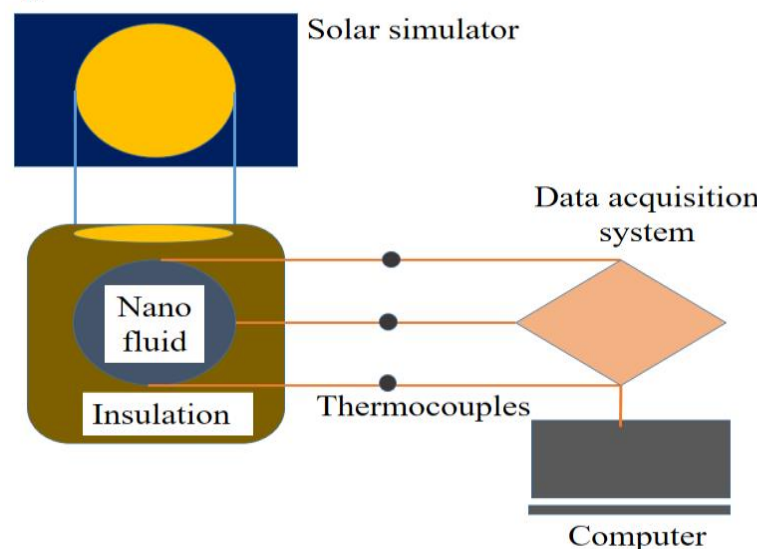

b

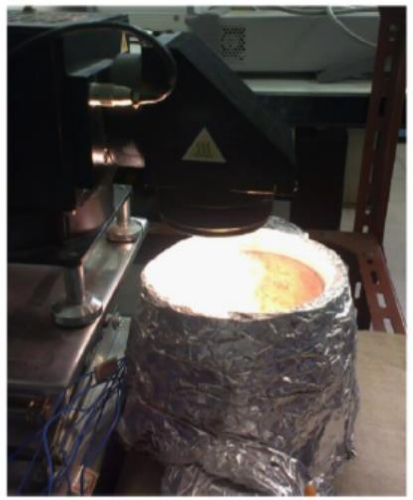

Fig. 9. (a) Schematic diagram of direct absorption solar thermal collector system; (b) Experimental setup with solar simulator and a receiver with graphene/[HMIM]BF 4 [108]. 
The conduction and convection heat transfer equation for solving the radioactive transfer equation was developed through numerical model of nanofluid solar collector. The nanofluids enhanced the efficiency and outlet temperature by $2-25 \%$ and $30-100 \mathrm{~K}$ respectively, than the base fluid [110]. The direct absorption solar thermal collectors using CNT nanofluids for study of high temperature and long-term stability of nanofluid was experimentally investigated. The solar energy absorption using MWCNTs was close to $100 \%$ at various concentrations of nanofluid due to its optical properties [74].

The $\mathrm{Ni}$ and $\mathrm{Cu}$ nanoparticle with $10 \mathrm{ppm}$ volume fraction has been compared through lowest transmittance and higher extinction coefficient in high-temperature DASCs to investigate the radiative properties of $[\mathrm{HMIM}]\left[\mathrm{NTf}_{2}\right]$. The incident light penetrated the nanofluid for a distance of $1 \mathrm{~cm}$ and absorbed $100 \%$ energy fraction [111]. The transmittance of nanofluid was affected from mass fraction, nanoparticle size and optical path. The $\mathrm{Cu}-\mathrm{H}_{2} \mathrm{O}$ nanofluid having transmittance is close to zero and $25.3 \%$ temperature was increased as compared to deionized water. The solar absorption efficiency can be enhanced by using $\mathrm{Cu}-\mathrm{H}_{2} \mathrm{O}$ nanofluids due to its photothermal properties [92], [112].

\subsection{Nanoparticles Uses Effect on Direct Absorption Solar Collector}

The nanotubes, graphene and copper nanoparticles were used by researcher. The cost of these nanoparticles is much higher than $\mathrm{Al}_{2} \mathrm{O}_{3}, \mathrm{SiO}_{2}$ and $\mathrm{TiO}_{2}$. Direct absorptions solar collector system is very complicated in construction and costly. $\mathrm{Al}_{2} \mathrm{O}_{3}, \mathrm{SiO}_{2}$ and $\mathrm{TiO}_{2}$ may be used with same system for lowering the system cost. Direct absorption system may be replaced by concentrated or non-concentrated solar collector to avoid the complications in the system. The thermosyphon is better option for the direct absorption solar collector system using nanofluid. The nanoparticles give much more heat transfer through thermosyphon unit.

\section{Concentric Solar Collector}

The capability evaluation of PTC using nanofluid was experimentally performed. A black chrome coating was introduced on copper tube to enhance the performance of the system. The vacuumed tube global efficiency was $11 \%$ higher than that of bare tube efficiency [10]. The heat transfer improvement of alumina/synthetic oil nanofluid in parabolic trough solar collector tube was studied numerically. The simulation and a turbulent mixed convection heat transfer with non-uniform heat flux was investigated by using a synthetic oil and $\mathrm{Al}_{2} \mathrm{O}_{3}$ nanofluid in a solar collector absorber tube $(L=7.8 \mathrm{~m}$ and $D=0.07 \mathrm{~m})$. Utilizing nanofluid in PTC has natural advantages and causes enhancing heat transfer [113], [114].

The parabolic concentrating solar collector using nanofluid for solar energy harvesting system was studied which is shown in Fig. 10. The analysis was carried out for terminol VP-1 as the base fluid and Aluminium nanoparticles with 0.05 vol\% suspended in it. It is found that the thermal efficiency of the system is about 5 to $10 \%$ higher than conventional parabolic solar collector under the same weather conditions [115].

An experimental performance was carried out on evacuated tubular solar collectors through open thermosyphon using nanofluid. It is seen that the mass concentration of $\mathrm{CuO}$ nanoparticles in open thermosyphon enhances the heat transfer effect up to $1.2 \%$ [116]. To evaluate the thermal efficiency of a cylindrical solar collector with helical pipe receiver using $\mathrm{CuO}-\mathrm{H}_{2} \mathrm{O}$ nanofluid an investigation was carried out as shown in Fig. 11. The $\mathrm{CuO}-\mathrm{H}_{2} \mathrm{O}$ nanofluids and distilled water were used as the working fluid for the experiment [117]. 


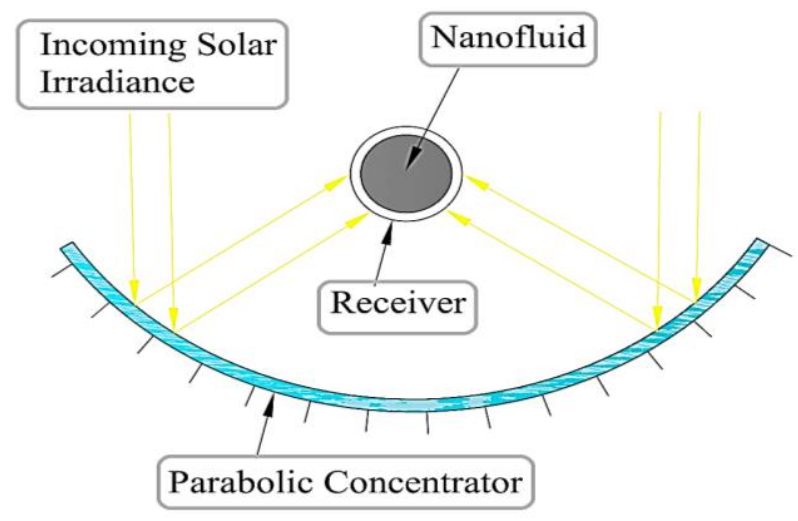

Fig. 10. Schematic diagram of parabolic concentrating solar collector using nanofluid [115].

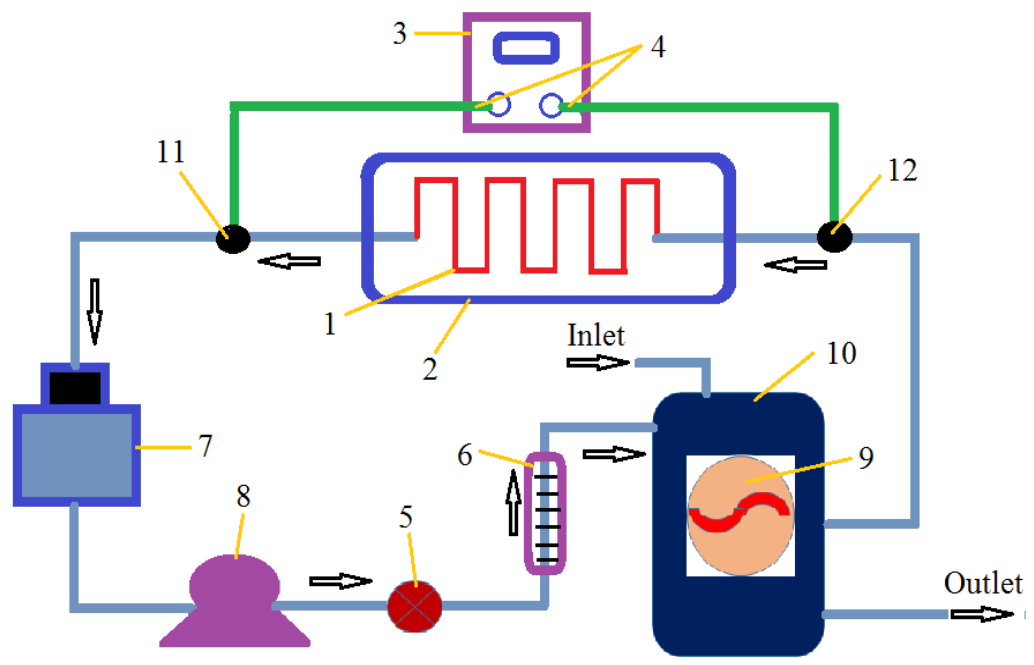

Fig. 11. Experimental setup. (1) Copper coil, (2) cylindrical glass, (3) datalogger system, (4) thermocouple wires, (5) line valve, (6) rotameter, (7) water supply and drainer, (8) water pump, (9) heat exchanger, (10) reservoir tank and (11 and 12) thermocouples [117].

The effect of therminol D-12 as the working fluid on the performance of evacuated tube solar collector coupled with parabolic trough was experimentally investigated. The temperature of the hot water produced was $40{ }^{\circ} \mathrm{C}$ at $06: 45 \mathrm{hr}$ in the presence of $0.240 \mathrm{~kW} / \mathrm{m}^{2}$ solar radiations [118].

\subsection{Concentric Solar Collector Efficiency Enhancement}

From the above discussion on the topic of concentrated solar collector using nanofluid is the better option to store energy in thermal storage. Researcher is getting more efficiency on this system. $\mathrm{Al}_{2} \mathrm{O}_{3}, \mathrm{CuO}, \mathrm{TiO}_{2}, \mathrm{SiO}_{2}$ nanoparticles is more suitable for the concentrated solar collector for the cooking, heating and industrial applications. Using nanofluid in concentrated solar collector for thermal storage system is more efficient and cheaper. 


\section{Discussion}

This paper introduced a survey of the utilizations of nanofluids in solar thermal engineering using $\mathrm{CuO}, \mathrm{SiO}_{2}, \mathrm{TiO}_{2}, \mathrm{Al}_{2} \mathrm{O}_{3}, \mathrm{CNT}$, graphene and graphite nanoparticles. It is worth to do an experimental investigation on the size of the nanoparticles.

In the solar collector and thermal storage system limited studies have been reported regarding the thermophysical properties of nanofluid. Only thermal conductivity is not important other properties also need to be taken into consideration [1]-[3]. Mixture of more than one nanoparticle in nanofluid is difficult and required new research in this area. Most of the researchers used water as base fluid for nanofluid preparation, so it is desired to search for the new suitable base fluid for the dispersion of nanoparticles. In this paper nanofluid with non-concentrated, concentrated, and direct absorption solar collector is deeply discussed. Effect of thermophysical, dimensional and chemical properties of nanoparticles on heat transfer system is discussed with applications. The enhancement of heat transfer efficiency in thermal storage system using nanofluid based solar collector is elaborated. Heat transfer through nanofluid use in thermal storage system is studied in detail. Table 4 shows the summary of applications of nanofluid in thermal energy based solar collectors.

\section{CONCLUSION AND RESEARCH IN FUTURE}

In the present paper, an endeavour has been made to survey different nanofluids based solar collector with thermal energy storage system. Nanotechnology is an established and effective innovation utilized for a long time. However, proper understanding of the role of nanoparticles in improving their performance will definitely provide more opportunities for developing nanofluid based solar collector. The efficiency and extinction coefficient of nanofluid depends on the diameter of nanoparticles and volume concentration.

Nanofluid based solar collectors and thermal storage systems are likely to overcome the challenges in the near future particularly for cooking industry. Experimental methods and procedure to take care of issues related to the utilization of PCMs such as supercooling, low thermal conductivity and incongruent melting through nanomaterial incorporation and encapsulation have also been presented.

From the above review it can be concluded that the nanofluids application in solar energy is still in its beginning periods. The major factors such as synthesis methods, production cost, physical and chemical parameters are affected from practical implications of nanofluids. So far, the hypothetical examinations have been accounted for on PTC; additional experimental studies can be performed. The introduction of nanotechnology in the future may overcome such problems with continuous research and development.

Thermo-physical properties of nanofluid are more suitable for the solar based thermal storage system using PCM with different nanoparticle size and volume are to be thought of for future work. The nanofluid for the solar collector with different nanoparticles require further research for different domestic application.

Solar collector based thermal storage system using nanofluid for the application of cooking, water heating, refrigeration etc. is the need of an hour. The physical, thermal and optical properties of nanofluid play an important role to enhance the performance of thermal storage system. Therefore, research on nanofluid with different nanoparticles size, shape and concentration is to be further carried out to analyse its different properties such as thermal conductivity, surface tension and viscosity, etc. 


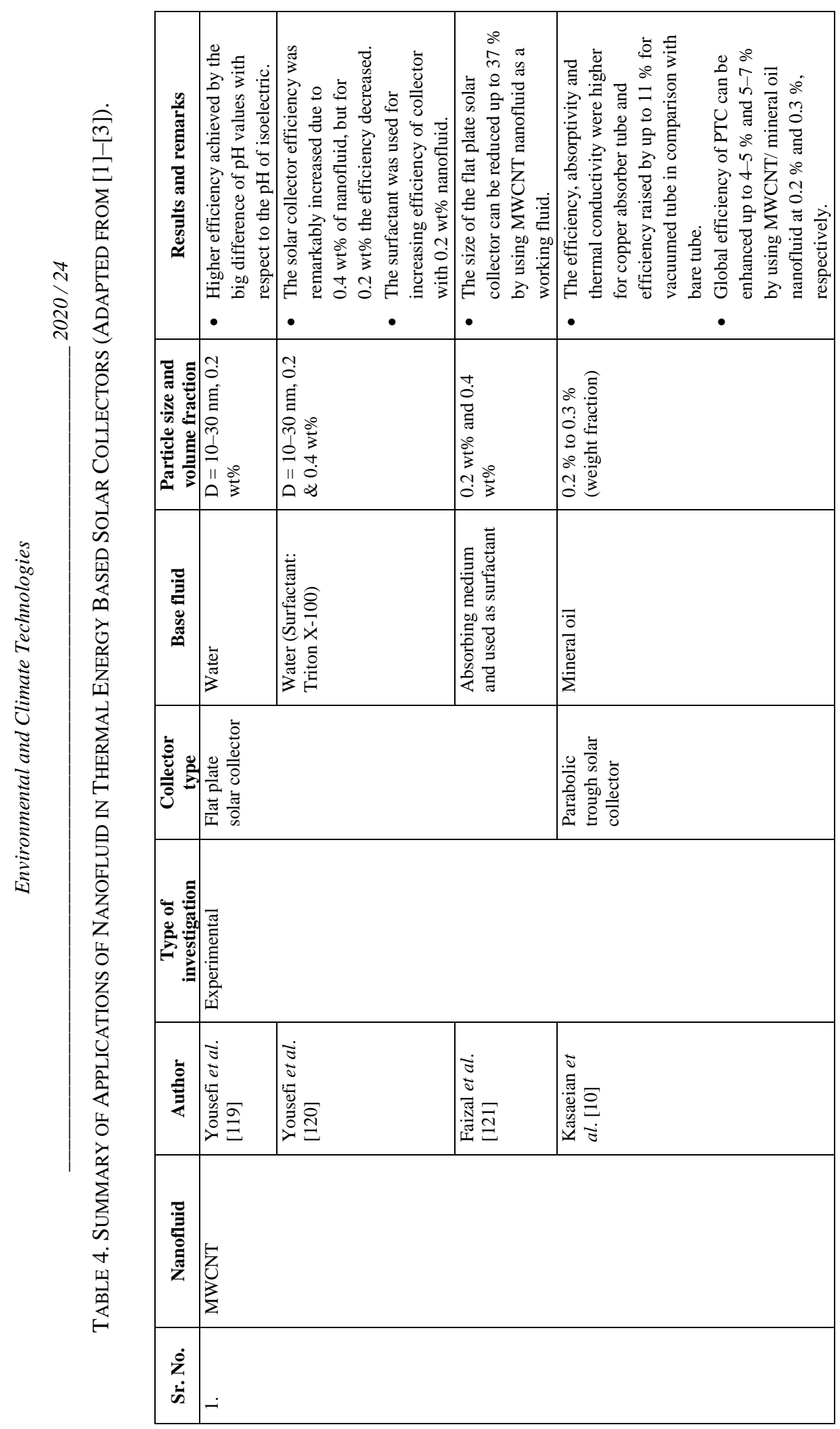

กิ 


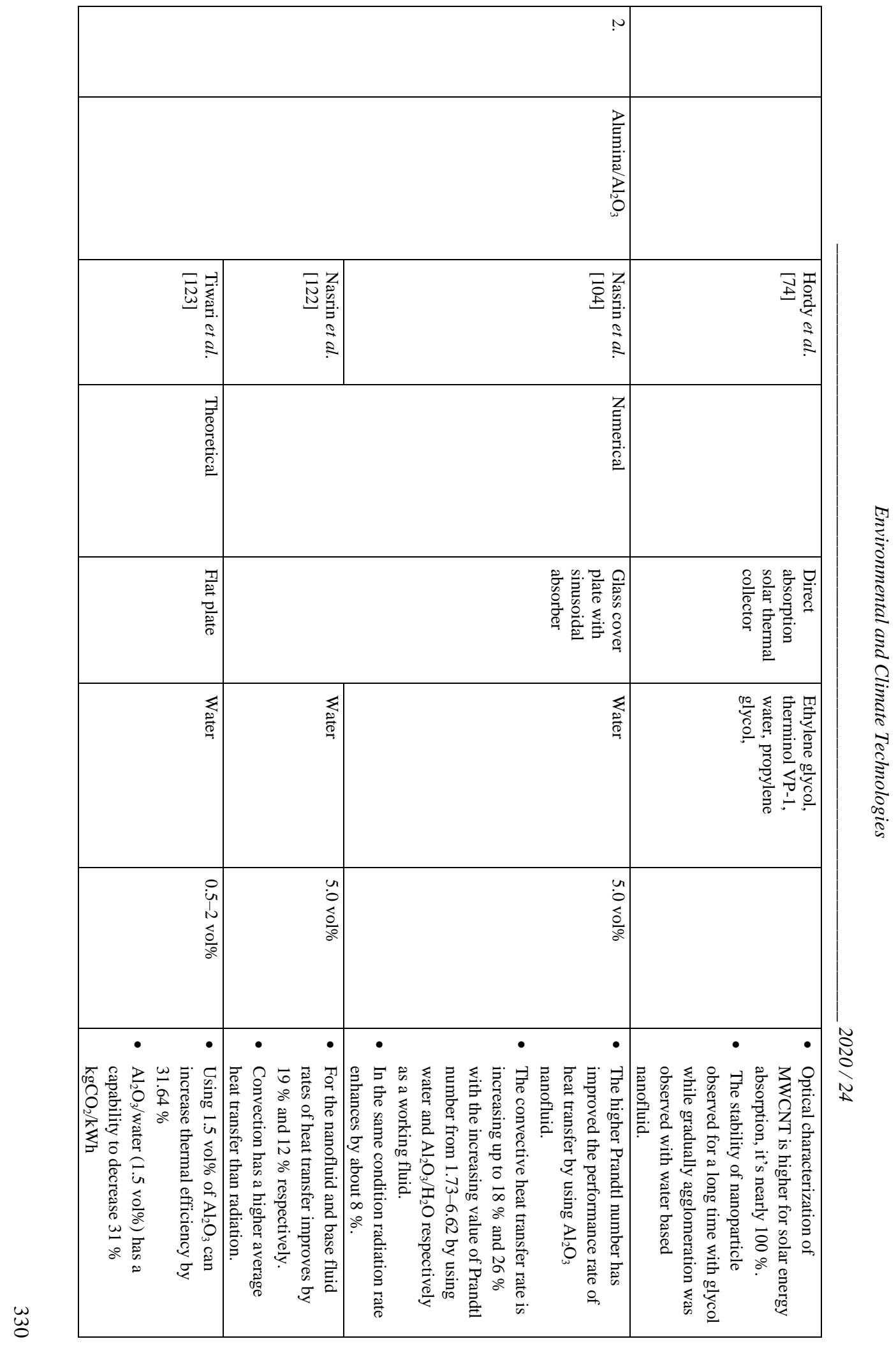




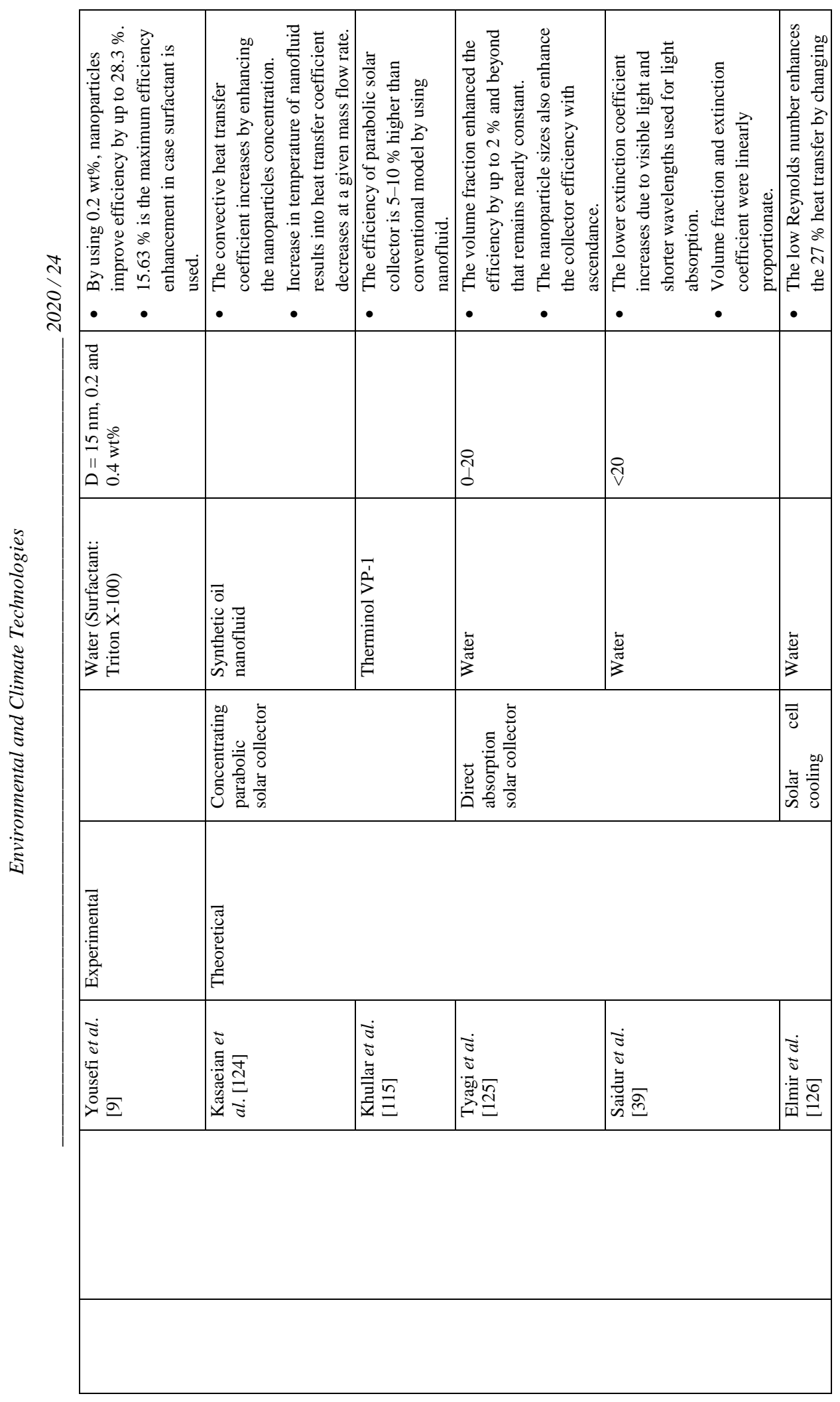




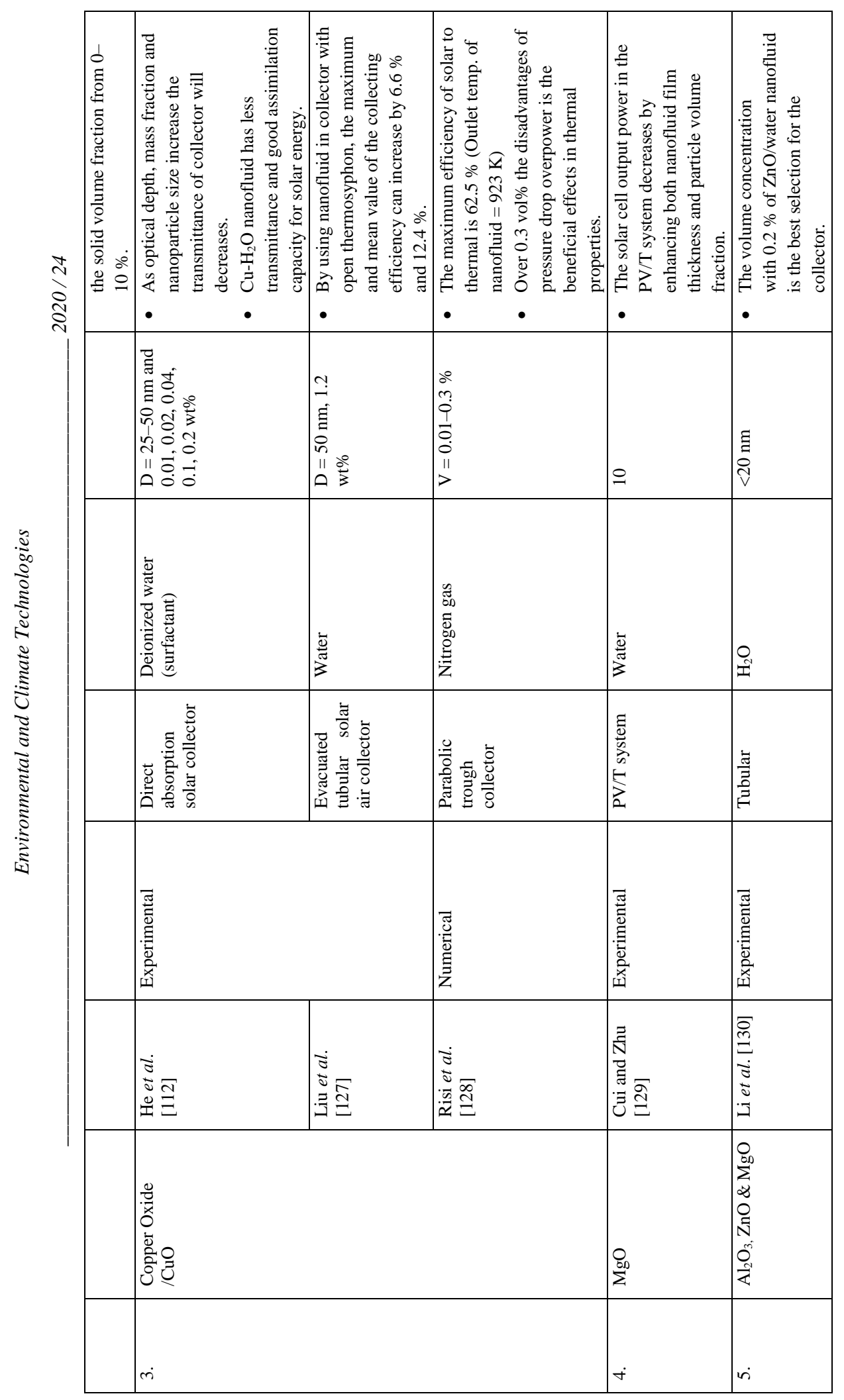




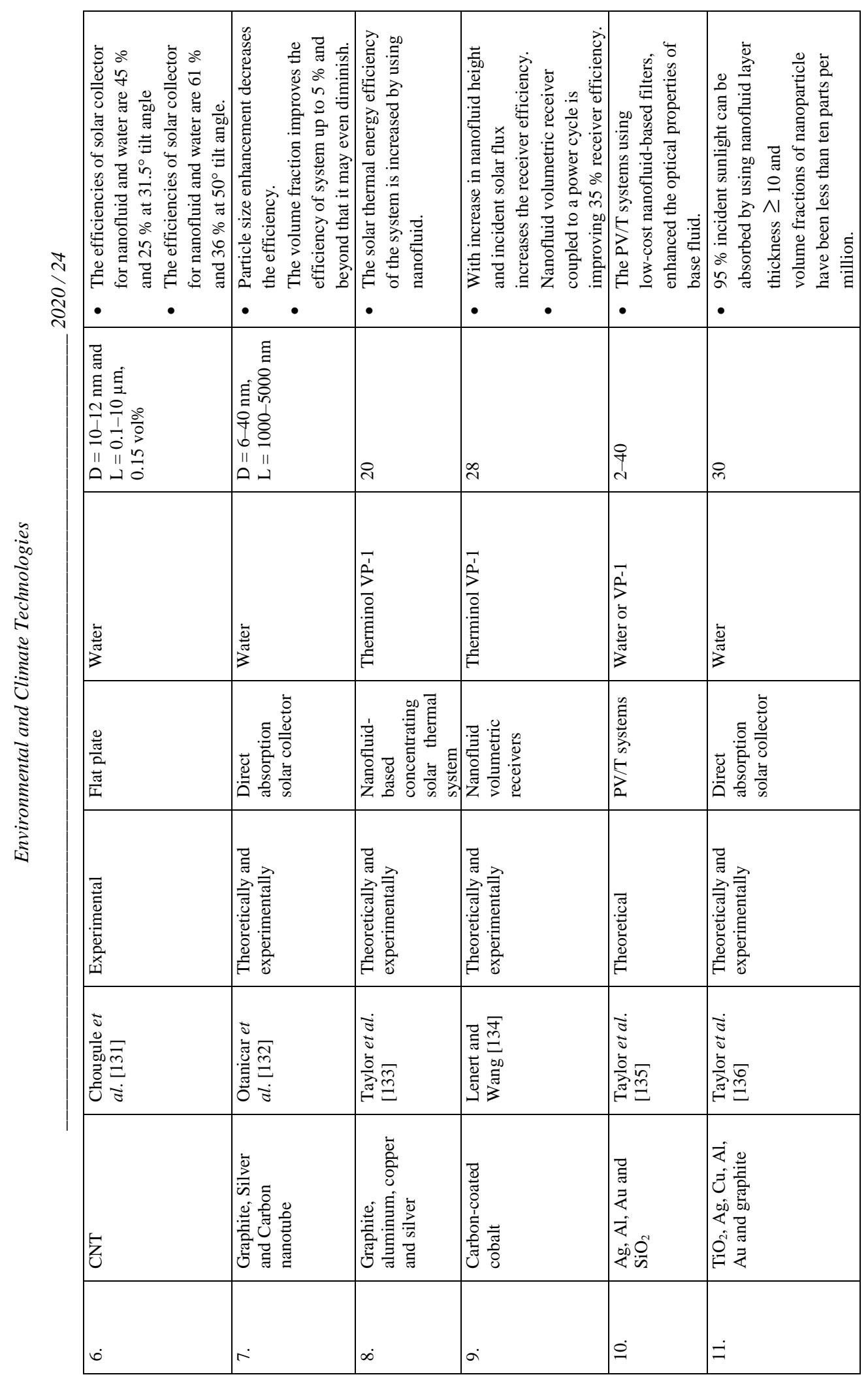




\section{REFERENCES}

[1] Nagarajan P. K., Subramani J., Suyambazhahan S., Sathyamurthy R. Nanofluids for solar collector applications: A review. Energy Procedia 2014:61:2416-2434. https://doi.org/10.1016/j.egypro.2014.12.017

[2] Javadi F. S., Saidur R., Kamalisarvestani M. Investigating performance improvement of solar collectors by using nanofluids. Reneable and Sustainable. Energy Reviews 2013:28:232-245. https://doi.org/10.1016/j.rser.2013.06.053

[3] Kasaeian A., Eshghi A. T., Sameti M. A review on the applications of nanofluids in solar energy systems. Renewable and Sustainable. Energy Reviews 2015:43:584-598. https://doi.org/10.1016/j.rser.2014.11.020

[4] Khanafer K., Vafai K. A review on the applications of nanofluids in solar energy field. Renewable Energy 2018:123:398-406. https://doi.org/10.1016/j.renene.2018.01.097

[5] Dheep G. R., Sreekumar A. Influence of nanomaterials on properties of latent heat solar thermal energy storage materials - A review. Energy Conversion and Management 2014:83:133-148. https://doi.org/10.1016/j.enconman.2014.03.058

[6] Al-Shamani A. N. et al. Nanofluids for improved efficiency in cooling solar collectors - A review. Renewable and Sustainable Energy Reviews 2014:38:348-367. https://doi.org/10.1016/j.rser.2014.05.041

[7] He Q., Zeng S., Wang S. Experimental investigation on the efficiency of flat-plate solar collectors with nanofluids. Applied Thermal Engineering 2015:88:165-171. https://doi.org/10.1016/j.applthermaleng.2014.09.053

[8] Said Z. et al. Performance enhancement of a Flat Plate Solar collector using Titanium dioxide nanofluid and Polyethylene Glycol dispersant. Journal of Cleaner Production 2015:92:343-353. https://doi.org/10.1016/j.jclepro.2015.01.007

[9] Yousefi T., Veysi F., Shojaeizadeh E., Zinadini S. An experimental investigation on the effect of A12O3-H2O nanofluid on the efficiency of flat-plate solar collectors. Renewable Energy 2012:39(1):293-298. https://doi.org/10.1016/j.renene.2011.08.056

[10] Kasaeian A., Daviran S., Azarian R. D., Rashidi A. Performance evaluation and nanofluid using capability study of a solar parabolic trough collector. Energy Conversion and Management 2015:89:368-375 https://doi.org/10.1016/j.enconman.2014.09.056

[11] Lee S. H., Jang S. P. Efficiency of a volumetric receiver using aqueous suspensions of multi-walled carbon nanotubes for absorbing solar thermal energy. International Journal of Heat and Mass Transfer 2015:80:58-71. https://doi.org/10.1016/j.ijheatmasstransfer.2014.08.091

[12] Rana P., Bhargava R., Bég O. A. Numerical solution for mixed convection boundary layer flow of a nanofluid along an inclined plate embedded in a porous medium. Computers and Mathematics with Application 2012:64(9):2816-2832. https://doi.org/10.1016/j.camwa.2012.04.014

[13] Yu W., Choi S. U. S. The role of interfacial layers in the enhanced thermal conductivity of nanofluids: A renovated Maxwell model. Journal of Nanoparticle Research 2003:5:167-171. https://doi.org/10.1023/A:1024438603801

[14] Choi S. U. S., Eastman J. A. Enhancing thermal conductivity of fluids with nanoparticles. Argonne National Lab., IL United States, 1995.

[15] Wang L., Fan J. Nanofluids research: Key issues. Nanoscale Research Letters 2010:5(8):1241-1252. https://doi.org/10.1007/s11671-010-9638-6

[16] Eastman J. A., Choi S. U. S., Li S., Yu W., Thompson L. J. Anomalously increased effective thermal conductivities of ethylene glycol-based nanofluids containing copper nanoparticles. Applied Physics Letters 2001:78(6):718-720. https://doi.org/10.1063/1.1341218

[17] Hong T.-K., Yang H.-S., Choi C. J. Study of the enhanced thermal conductivity of Fe nanofluids. Journal of Applied Physics 2005:97(6):64311. https://doi.org/10.1063/1.1861145

[18] Das S. K., Putra N., Thiesen P., Roetzel W. Temperature Dependence of Thermal Conductivity Enhancement for Nanofluids. Journal of Heat Transfer 2003:125(4)567. https://doi.org/10.1115/1.1571080

[19] Patel H. E., Das S. K., Sundararajan T., Sreekumaran Nair A., George B., Pradeep T. Thermal conductivities of naked and monolayer protected metal nanoparticle based nanofluids: Manifestation of anomalous enhancement and chemical effects. Applied Physics Letters 2003:83(14):2931-2933. https://doi.org/10.1063/1.1602578.

[20] Kamyar A., Saidur R., Hasanuzzaman M. Application of Computational Fluid Dynamics (CFD) for nanofluids. International Journal of Heat and Mass Transfer 2012:55(15-16):4104-4115. https://doi.org/10.1016/j.ijheatmasstransfer.2012.03.052

[21] Namburu P. K., Kulkarni D. P., Dandekar A., Das D. K. Experimental investigation of viscosity and specific heat of silicon dioxide nanofluids. Micro \& Nano Letters 2007:2(3):67-71. https://doi.org/10.1049/mnl:20070037

[22] Collins P. G., Avouris P. Nanotubes for electronics. Scientific American 2000:283(6):62-69. https://doi.org/10.1038/scientificamerican1200-62

[23] Kumar H. G. P., Xavior M. A., Ashwath P. Ultrasonication and microwave processing of aluminum alloy-Graphene- $\mathrm{Al}_{2} \mathrm{O}_{3}$ nanocomposite. Materials and Manufacturing Processes 2018:33(1):13-18. https://doi.org/10.1080/10426914.2016.1244852 
[24] Yuan W., Zhang Y., Cheng L., Wu H., Zheng L., Zhao D. The applications of carbon nanotubes and graphene in advanced rechargeable lithium batteries. Journal of Materials Chemistry A 2016:4(23):8932-8951. https://doi.org/10.1039/C6TA01546H

[25] Pop E., Varshney V., Roy A. K. Thermal properties of graphene: Fundamentals and applications. MRS Bulletin 2012:37(12):1273-1281. https://doi.org/10.1557/mrs.2012.203

[26] Faizal M., Saidur R., Mekhilef S., Alim M. A. Energy, economic and environmental analysis of metal oxides nanofluid for flat-plate solar collector. Energy Conversion and Management 2013:76:162-168. https://doi.org/10.1016/j.enconman.2013.07.038

[27] Turkyilmazoglu M. Anomalous heat transfer enhancement by slip due to nanofluids in circular concentric pipes. International Journal of Heat and Mass Transfer 2015:85:609-614. doi: https://doi.org/10.1016/j.ijheatmasstransfer.2015.02.015

[28] Jamshed W., Aziz A. A comparative entropy based analysis of $\mathrm{Cu}$ and $\mathrm{Fe}_{3} \mathrm{O}_{4} /$ methanol Powell-Eyring nanofluid in solar thermal collectors subjected to thermal radiation, variable thermal conductivity and impact of different nanoparticles shape. Results in Physics 2018:9:195-205. https://doi.org/10.1016/j.rinp.2018.01.063

[29] Cárdenas Contreras E. M., Oliveira G. A., Bandarra Filho E. P. Experimental analysis of the thermohydraulic performance of graphene and silver nanofluids in automotive cooling systems. International Journal of Heat and Mass Transfer 2019:132:375-387. https://doi.org/10.1016/j.ijheatmasstransfer.2018.12.014

[30] Elsheikh A. H., Sharshir S. W., Mostafa M. E., Essa F. A., Ahmed Ali M. K. Applications of nanofluids in solar energy: A review of recent advances. Renewable and Sustainable Energy Reviews 2017:82:3483-3502. https://doi.org/10.1016/j.rser.2017.10.108

[31] Ganvir R. B., Walke P. V., Kriplani V. M. Heat transfer characteristics in nanofluid-A review. Renewable and Sustainable Energy Reviews 2015:75:451-460. https://doi.org/10.1016/j.rser.2016.11.010

[32] Gulum M., Bilgin A. An experimental optimization research of methyl and ethyl esters production from safflower oil. Environmental and Climate Technologies 2018:22(1):132-148. https://doi.org/10.2478/rtuect-2018-0009

[33] Bait O., Si-Ameur M. Enhanced heat and mass transfer in solar stills using nanofluids: A review. Solar Energy 2018:170:694-722. https://doi.org/10.1016/j.solener.2018.06.020

[34] Babar H., Sajid M., Ali H. Viscosity of hybrid nanofluids: A critical review. Thermal Science 2019:23(3B):1713-1754. https://doi.org/10.2298/tsci181128015b

[35] Sajid M. U., Ali H. M. Recent advances in application of nanofluids in heat transfer devices: A critical review. Renewable and Sustainable Energy Reviews 2019:103:556-592. https://doi.org/10.1016/j.rser.2018.12.057

[36] Bazri S., Badruddin I. A., Naghavi M. S., Bahiraei M. A review of numerical studies on solar collectors integrated with latent heat storage systems employing fins or nanoparticles. Renewable Energy 2018:118:761-778. https://doi.org/10.1016/j.renene.2017.11.030

[37] Verma S. K., Tiwari A. K. Progress of nanofluid application in solar collectors: A review. Energy Conversion and Management 2015:100:324-346. https://doi.org/10.1016/j.enconman.2015.04.071

[38] Yang L., Du K. A comprehensive review on heat transfer characteristics of TiO2 nanofluids. International Journal of Heat and Mass Transfer 2017:108(A):11-31 https://doi.org/10.1016/j.ijheatmasstransfer.2016.11.086

[39] Saidur R., Meng T. C., Said Z., Hasanuzzaman M., Kamyar A. Evaluation of the effect of nanofluid-based absorbers on direct solar collector. International Journal of Heat and Mass Transfer 2012:55(21-22):5899-5907. https://doi.org/10.1016/j.ijheatmasstransfer.2012.05.087

[40] Faizal M., Saidur R., Mekhilef S., Faizal M. Potential of Size Reduction of Flat-Plate Solar Collectors when Applying $\mathrm{Al}_{2} \mathrm{O}_{3} \quad$ Nanofluid. Advanced $\quad$ Material Research 2014:832:149-153 https://doi.org/10.4028/www.scientific.net/amr.832.149

[41] Lomascolo M., Colangelo G., Milanese M., Risi A. De. Review of heat transfer in nanofluids: Conductive, convective and radiative experimental results. Renewable and Sustainable Energy Reviews 2015:43:1182-1198 https://doi.org/10.1016/j.rser.2014.11.086

[42] Vajjha R. S., Das D. K., Kulkarni D. P. Development of new correlations for convective heat transfer and friction factor in turbulent regime for nanofluids. International Journal of Heat and Mass Transfer 2010:53:(21-22):4607-4618 https://doi.org/10.1016/j.ijheatmasstransfer.2010.06.032

[43] Xie H., Wang J., Xi T., Liu Y., Ai F., Wu Q. Thermal conductivity enhancement of suspensions containing nanosized alumina particles. Journal of Applied Physics 2002:91(7):4568-4572. https://doi.org/10.1063/1.1454184

[44] Gherasim I., Roy G., Nguyen C. T., Vo-Ngoc D. Experimental investigation of nanofluids in confined laminar radial flows. International Journal of Thermal Science 2009:48(8):1486-1493 https://doi.org/10.1016/j.ijthermalsci.2009.01.008

[45] Peyghambarzadeh S. M., Hashemabadi S. H., Jamnani M. S., Hoseini S. M. Improving the cooling performance of automobile radiator with $\mathrm{Al}_{2} \mathrm{O}_{3}$ /water nanofluid. Applied Thermal Engineering 2011:31(10):1833-1838. https://doi.org/10.1016/j.applthermaleng.2011.02.029

[46] Putra N., Yanuar, Iskandar F. N. Application of nanofluids to a heat pipe liquid-block and the thermoelectric cooling of electronic equipment. Experimental Thermal and Fluid Sciences 2011:35(7):1274-1281. https://doi.org/10.1016/j.expthermflusci.2011.04.015 
[47] Bhogare R. A., Kothawale B. S. Performance investigation of Automobile Radiator operated with Nanofluids Based Coolant. IOSR Journal of Mechanical and Civil Engineering 2014:11(3):23-30. https://doi.org/10.9790/168411352330 .

[48] Mehtre D. N., Kore S. S. Experimental Analysis of Heat Transfer From Car Radiator Using Nanofluids. International Journal of Medicinal Chemistry and Analysis 2014:2(4):101-106.

[49] Mohammed H. A., Gunnasegaran P., Shuaib N. H. Heat transfer in rectangular microchannels heat sink using nanofluids. International Communications in Heat and Mass Transfer 2010:37(10):1496-1503. https://doi.org/10.1016/j.icheatmasstransfer.2010.08.020

[50] Shalchi-Tabrizi A., Seyf H. R. Analysis of entropy generation and convective heat transfer of Al $2 \mathrm{O} 3$ nanofluid flow in a tangential micro heat sink. International Journal of Heat and Mass Transfer 2012:55(15-16):4366-4375. https://doi.org/10.1016/j.ijheatmasstransfer.2012.04.005

[51] Tiecher R. F. P., Parise J. A. R. A comparative parametric study on single-phase Al2O3-water nanofluid exchanging heat with a phase-changing fluid. International Journal of Thermal Sciences 2014:74:190-198. https://doi.org/10.1016/j.ijthermalsci.2013.06.014

[52] Naraki M., Peyghambarzadeh S. M., Hashemabadi S. H., Vermahmoudi Y. Parametric study of overall heat transfer coefficient of $\mathrm{CuO}$ /water nanofluids in a car radiator. International Journal of Thermal Sciences 2013:66:82-90 https://doi.org/10.1016/j.ijthermalsci.2012.11.013

[53] Khairul M. A., Saidur R., Rahman M. M., Alim M. A., Hossain A., Abdin Z. Heat transfer and thermodynamic analyses of a helically coiled heat exchanger using different types of nanofluids. International Journal of Heat and Mass Transfer 2013:67:398-403. https://doi.org/10.1016/j.ijheatmasstransfer.2013.08.030

[54] Wen D., Ding Y. Experimental investigation into convective heat transfer of nanofluids at the entrance region under laminar flow conditions. International Journal of Heat and Mass Transfer 2004:47(24):5181-5188. https://doi.org/10.1016/j.ijheatmasstransfer.2004.07.012.

[55] Namburu P. K., Das D. K., Tanguturi K. M., Vajjha R. S. Numerical study of turbulent flow and heat transfer characteristics of nanofluids considering variable properties. International Journal of Thermal Sciences 2009:48(2):290-302. https://doi.org/10.1016/j.ijthermalsci.2008.01.001

[56] Lee S., Choi S. U.-S., Li S., Eastman J. A. Measuring Thermal Conductivity of Fluids Containing Oxide Nanoparticles. Journal of Heat Transfer 1999:121(2):280. https://doi.org/10.1115/1.2825978

[57] Seyf H. R., Feizbakhshi V. Computational analysis of nanofluid effects on convective heat transfer enhancement of micro-pin-fin heat sinks. International Journal of Thermal Sciences 2012:58:168-179. https://doi.org/10.1016/j.ijthermalsci.2012.02.018.

[58] Choi S. U., Eastman J., Phillpot S., Keblinski P. Mechanisms of heat flow in suspensions of nano-sized particles (nanofluids). International Journal of Heat and Mass Transfer 2002:45(4):855-863. https://doi.org/10.1016/S00179310(01)00175-2

[59] Jmai R., Ben-Beya B., Lili T. Heat transfer and fluid flow of nanofluid-filled enclosure with two partially heated side walls and different nanoparticles. Superlattices and Microstructures 2013:53(1):130-154. https://doi.org/10.1016/j.spmi.2012.10.003

[60] Xuan Y., Li Q. Investigation on Convective Heat Transfer and Flow Features of Nanofluids. Journal of Heat and Mass Transfer 2003:125(1):151. https://doi.org/10.1115/1.1532008

[61] Putra N., Roetzel W., Das S. K. Natural convection of nano-fluids. Journal of Heat and Mass Transfer und Stoffuebertragung 2003:39(8-9):775-784. https://doi.org/10.1007/s00231-002-0382-Z

[62] Huminic G., Huminic A. Heat transfer characteristics in double tube helical heat exchangers using nanofluids. International Journal of Heat and Mass Transfer 2011:54(19-20):4280-4287. https://doi.org/10.1016/j.ijheatmasstransfer.2011.05.017

[63] Chandrasekar M., Suresh S., Chandra Bose A. Experimental studies on heat transfer and friction factor characteristics of $\mathrm{Al}_{2} \mathrm{O}_{3}$ /water nanofluid in a circular pipe under laminar flow with wire coil inserts. Experimental Thermal and Fluid Science 2009:34(2):122-130. https://doi.org/10.1016/j.expthermflusci.2009.10.001

[64] Suresh S., Venkitaraj K. P., Selvakumar P. Comparative study on thermal performance of helical screw tape inserts in laminar flow using $\mathrm{Al}_{2} \mathrm{O}_{3}$ /water and $\mathrm{CuO}$ /water nanofluids. Superlattices and Microstructures 2011:49(6):608-622. https://doi.org/10.1016/j.spmi.2011.03.012

[65] Zamzamian A., Oskouie S. N., Doosthoseini A., Joneidi A., Pazouki M. Experimental investigation of forced convective heat transfer coefficient in nanofluids of $\mathrm{Al}_{2} \mathrm{O}_{3} / \mathrm{EG}$ and $\mathrm{CuO} / \mathrm{EG}$ in a double pipe and plate heat exchangers under turbulent flow. Experimental Thermal and Fluid Science 2011:35(3):495-502. https://doi.org/10.1016/j.expthermflusci.2010.11.013

[66] Keshavarz Moraveji M., Esmaeili E. Comparison between single-phase and two-phases CFD modeling of laminar forced convection flow of nanofluids in a circular tube under constant heat flux. International Communications in Heat and Mass Transfer 2012:39(8):1297-1302. https://doi.org/10.1016/j.icheatmasstransfer.2012.07.012

[67] Anoop K. B., Sundararajan T., Das S. K. Effect of particle size on the convective heat transfer in nanofluid in the developing region. International Journal of Heat and Mass Transfer 2009:52(9-10):2189-2195. https://doi.org/10.1016/j.ijheatmasstransfer.2007.11.063 
[68] Ahmed M. A., Shuaib N. H., Yusoff M. Z., Al-Falahi A. H. Numerical investigations of flow and heat transfer enhancement in a corrugated channel using nanofluid. International Communications in Heat and Mass Transfer 2011:38(10):1368-1375. https://doi.org/10.1016/j.icheatmasstransfer.2011.08.013

[69] Garoosi F., Bagheri G., Talebi F. Numerical simulation of natural convection of nanofluids in a square cavity with several pairs of heaters and coolers (HACs) inside. International Journal of Heat and Mass Transfer 2013:67:362376. https://doi.org/10.1016/j.ijheatmasstransfer.2013.08.034.

[70] Fotukian S. M., Nasr Esfahany M. Experimental study of turbulent convective heat transfer and pressure drop of dilute $\mathrm{CuO} /$ water nanofluid inside a circular tube. International Communications of Heat and Mass Transfer 2010:37(2):214 219. https://doi.org/10.1016/j.icheatmasstransfer.2009.10.003

[71] Daviran S., Kasaeian A., Tahmooressi H., Rashidi A., Wen D., Mahian O. Evaluation of clustering role versus Brownian motion effect on the heat conduction in nanofluids: A novel approach. International Journal of Heat and Mass Transfer 2017:108(A):822-829. https://doi.org/10.1016/j.ijheatmasstransfer.2016.12.071

[72] Fan L., Khodadadi J. M. Thermal conductivity enhancement of phase change materials for thermal energy storage: a review. Renewable and Sustainable Energy Reviews 2011:15(1):24-46. https://doi.org/10.1016/j.rser.2010.08.007

[73] Dehury P., Singh J., Banerjee T. Thermophysical and Forced Convection Studies on (Alumina + Menthol)-Based Deep Eutectic Solvents for Their Use as a Heat Transfer Fluid. ACS Omega 2018:3(12):18016-18027. https://doi.org/10.1021/acsomega.8b02661

[74] Hordy N., Rabilloud D., Meunier J. L., Coulombe S. High temperature and long-term stability of carbon nanotube nanofluids for direct absorption solar thermal collectors. Solar Energy 2014:105:82-90. https://doi.org/10.1016/j.solener.2014.03.013

[75] Kalbande V. P., Walke P. V. Oil-and Aluminum-Based Thermal Storage System Using Flat Plate Solar Collector. In Kolhe M., Labhasetwar P., Suryawanshi H. (eds) Smart Technologies for Energy, Environment and Sustainable Development. Lecture Notes on Multidisciplinary Industrial Engineering. Springer, 2019:553-562. https://doi.org/10.1007/978-981-13-6148-7 53

[76] Arshad W., Ali H. M. Graphene nanoplatelets nanofluids thermal and hydrodynamic performance on integral fin heat sink. International Journal of Heat and Mass Transfer 2017:107:995-1001. https://doi.org/10.1016/j.ijheatmasstransfer.2016.10.127

[77] Gan Y., Qiao L. Optical properties and radiation-enhanced evaporation of nanofluid fuels containing carbon-based nanostructures. Energy and Fuels 2012:26(7):4224-4230. https://doi.org/10.1021/ef300493m

[78] Mussard M., Nydal O. J. Charging of a heat storage coupled with a low-cost small-scale solar parabolic trough for cooking purposes. Solar Energy 2013:95:144-154. https://doi.org/10.1016/j.solener.2013.06.013

[79] Mussard M., Nydal O. J. Comparison of oil and aluminum-based heat storage charged with a small-scale solar parabolic trough. Applied Thermal Engineering 2013:58(1-2):146-154. https://doi.org/10.1016/j.applthermaleng.2013.03.059

[80] Mussard M., Gueno A., Nydal O. J. Experimental study of solar cooking using heat storage in comparison with direct heating. Solar Energy 2013:98(C):375-383. https://doi.org/10.1016/j.solener.2013.09.015

[81] Rucevskis S., Akishin P., Korjakins A. Performance Evaluation of an Active PCM Thermal Energy Storage System for Space Cooling in Residential Buildings. Environmental and Climate Technologies 2019:23(2):74-89. https://doi.org/10.2478/rtuect-2019-0056

[82] Sirmelis R., Vanaga R., Freimanis R., Blumberga A. Solar Facade Module for Nearly Zero Energy Building. Optimization Strategies Environmental and Climate Technologies 2019:23(3):170-181. https://doi.org/10.2478/rtuect2019-0087

[83] Sharma A., Tyagi V. V., Chen C. R., Buddhi D. Review on thermal energy storage with phase change materials and applications. Renewable and Sustainable Energy Reviews 2009:13(2):318-345 https://doi.org/10.1016/j.rser.2007.10.005

[84] Ebrahimnia-Bajestan E., Charjouei Moghadam M., Niazmand H., Daungthongsuk W., Wongwises S. Experimental and numerical investigation of nanofluids heat transfer characteristics for application in solar heat exchangers. International Journal of Heat and Mass Transfer. 2016:92:1041-1052. https://doi.org/10.1016/j.ijheatmasstransfer.2015.08.107

[85] Wang W., Wu Z., Li B., Sundén B. A review on molten-salt-based and ionic-liquid-based nanofluids for medium-tohigh temperature heat transfer. Journal of Thermal Analysis and Calorimetry 2019:136(3):1037-1051. https://doi.org/10.1007/s10973-018-7765-y

[86] Mussard M. A solar concentrator with heat storage and self-circulating liquid. Norwegian University of Science and Technology, 2013.

[87] Kalbande V. P., Walke P. V., Shelke R. Aluminum-based thermal storage system with solar collector using nanofluid. Energy Storage 2019:1(6):1-7. https://doi.org/10.1002/est2.99.

[88] Gálvez B. J., et al. Solar Energy Conversion and Photoenergy System-Volume II. EOLSS, 2009.

[89] Notton G., Motte F., Cristofari C., Canaletti J. L. Performances and numerical optimization of a novel thermal solar collector for residential building. Renewable and Sustainable Energy Reviews 2014:33:60-73. https://doi.org/10.1016/j.rser.2014.01.061 
[90] Albatayneh A., Alterman D., Page A., Moghtaderi B. The significance of temperature based approach over the energy based approaches in the buildings thermal assessment. Environmental and Climate Technologies 2017:19(1):39-50. https://doi.org/10.1515/rtuect-2017-0004

[91] Tagliafico L. A., Scarpa F., De Rosa M. Dynamic thermal models and CFD analysis for flat-plate thermal solar collectors - A review. Renewable and Sustainable Energy Reviews 2014:30:526-537. https://doi.org/10.1016/j.rser.2013.10.023

[92] Al-Waeli A. H. A., Chaichan M. T., Sopian K., Kazem H. A., Mahood H. B., Khadom A. A. Modeling and experimental validation of a PVT system using nanofluid coolant and nano-PCM. Solar Energy 2018:177:178-191. https://doi.org/10.1016/j.solener.2018.11.016.

[93] Lari M. O., Sahin A. Z. Effect of retrofitting a silver/water nanofluid-based photovoltaic/thermal (PV/T) system with a PCM-thermal battery for residential applications. Renewable Energy 2018:122:98-107. https://doi.org/10.1016/j.renene.2018.01.034

[94] Kabeel A. E., El-Said E. M. S. Applicability of flashing desalination technique for small scale needs using a novel integrated system coupled with nanofluid-based solar collector. Desalination 2014:333(1):10-22. https://doi.org/10.1016/j.desal.2013.11.021.

[95] Said Z., Saidur R., Rahim N. A., Alim M. A. Analyses of exergy efficiency and pumping power for a conventional flat plate solar collector using SWCNTs based nanofluid. Energy and Buildings 2014:78:1-9. https://doi.org/10.1016/j.enbuild.2014.03.061

[96] Schuchardt G. K. Integration of decentralized thermal storages within district heating (DH) networks. Environmental and Climate Technologies 2016:18(1):5-16. https://doi.org/10.1515/rtuect-2016-0009.

[97] Nasrin R., Alim M. A. Semi-empirical relation for forced convective analysis through a solar collector. Solar Energy 2014:105:455-467. https://doi.org/10.1016/j.solener.2014.03.035

[98] Al-Kayiem H. H., Lin S. C. Performance evaluation of a solar water heater integrated with a PCM nanocomposite TES at various inclinations. Solar Energy 2014:109(1):82-92. https://doi.org/10.1016/j.solener.2014.08.021.

[99] Sekhar Y. R., Sharma K. V., Karupparaj R. T., Chiranjeevi C. Heat transfer enhancement with Al2O3 nanofluids and twisted tapes in a pipe for solar thermal applications. Procedia Engineering 2013:64:1474-1484. https://doi.org/10.1016/j.proeng.2013.09.229

[100] Prakasam M. J. S., Thottipalayam Vellingiri A. T., Nataraj S. An experimental study of the mass flow rates effect on flat-plate solar water heater performance using Al2O3/water nanofluid. Thermal Science 2017:21:379-388. https://doi.org/10.2298/TSCI17S2379P.

[101] Dasaien A. V., Elumalai N. Performance Enhancement Studies in a Thermosyphon Flat Plate Solar Water Heater with CuO Nanofluid. Thermal science 2017:21:6B:2757-2768.

[102]Colangelo G., Milanese M., and De Risi A. Numerical simulation of thermal efficiency of an innovative Al2O3nanofluid solar thermal collector influence of nanoparticles concentration. Thermal Science 2017:21(6B):27692779. https://doi.org/10.2298/TSCI151207168C

[103]Colangelo G., Favale E., De Risi A., Laforgia D. A new solution for reduced sedimentation flat panel solar thermal collector using nanofluids. Applied Energy 2013:111:80-93. https://doi.org/10.1016/j.apenergy.2013.04.069

[104] Nasrin R., Parvin S., Alim M. A. Effect of Prandtl number on free convection in a solar collector filled with nanofluid. Procedia Engineering 2013:56:54-62. https://doi.org/10.1016/j.proeng.2013.03.088

[105]Hatami M., Khazayinejad M., Zhou J., Jing D. Three-dimensional and two-phase nanofluid flow and heat transfer analysis over a stretching infinite solar plate. Thermal Science 2018:22(2):871-884 https://doi.org/10.2298/TSCI160614266H

[106] Karami M., Akhavan Bahabadi M. A., Delfani S., Ghozatloo A. A new application of carbon nanotubes nanofluid as working fluid of low-temperature direct absorption solar collector. Solar Energy Materials and Solar Cells 2014:121:114-118. https://doi.org/10.1016/j.solmat.2013.11.004

[107] Gupta H. K., Das Agrawal G., Mathur J. Investigations for effect of Al2O3-H2O nanofluid flow rate on the efficiency of direct absorption solar collector. Case Studies in Thermal Engineering 2015:5:70-78. https://doi.org/10.1016/j.csite.2015.01.002

[108] Liu J., Ye Z., Zhang L., Fang X., Zhang Z. A combined numerical and experimental study on graphene/ionic liquid nanofluid based direct absorption solar collector. Solar Energy Materials and Solar Cells 2015:136:177-186. https://doi.org/10.1016/j.solmat.2015.01.013

[109] Ali H. M., Arshad W. Effect of channel angle of pin-fin heat sink on heat transfer performance using water based graphene nanoplatelets nanofluids. International Journal of Heat and Mass Transfer 2017:106:465-472. https://doi.org/10.1016/j.ijheatmasstransfer.2016.08.061

[110] Luo Z., Wang C., Wei W., Xiao G., Ni M. Performance improvement of a nanofluid solar collector based on direct absorption collection (DAC) concepts. International Journal of Heat and Mass Transfer 2014:75:262-271. https://doi.org/10.1016/j.ijheatmasstransfer.2014.03.072

[111]Zhang L., Liu J., He G., Ye Z., Fang X., Zhang Z. Radiative properties of ionic liquid-based nanofluids for mediumto-high-temperature direct absorption solar collectors. Solar Energy Materials and Solar Cells 2014:130:521-528. https://doi.org/10.1016/j.solmat.2014.07.040 
[112]He Q., Wang S., Zeng S., Zheng Z. Experimental investigation on photothermal properties of nanofluids for direct absorption solar thermal energy systems. Energy Conversion and Management 2013:73:150-157. https://doi.org/10.1016/j.enconman.2013.04.019

[113] Sokhansefat T., Kasaeian A. B., Kowsary F. Heat transfer enhancement in parabolic trough collector tube using $\mathrm{Al}_{2} \mathrm{O}_{3}$ /synthetic oil nanofluid. Renewable and Sustainable Energy Reviews 2014:33:636-644. https://doi.org/10.1016/j.rser.2014.02.028.

[114] Ghasemi S. E., Ranjbar A. A. Effect of using nanofluids on efficiency of parabolic trough collectors in solar thermal electric power plants. International Journal of Hydrogen Energy 2017:42(34):21626-21634 https://doi.org/10.1016/j.ijhydene.2017.07.087

[115] Khullar V., Tyagi H., Phelan P. E., Otanicar T. P., Singh H., Taylor R. A. Solar energy harvesting using nanofluidsbased concentrating solar collector. Journal of Nanotechnology in Engineering and Medicine 2012:3(3):31003. https://doi.org/10.1115/1.4007387

[116] Lu L., Liu Z. H., Xiao H. S. Thermal performance of an open thermosyphon using nanofluids for high-temperature evacuated tubular solar collectors. Part 1: Indoor experiment. Solar Energy 2011:85(2):379-387. https://doi.org/10.1016/j.solener.2010.11.008

[117] Goudarzi K., Shojaeizadeh E., Nejati F. An experimental investigation on the simultaneous effect of $\mathrm{CuO}-\mathrm{H}_{2} \mathrm{O}$ nanofluid and receiver helical pipe on the thermal efficiency of a cylindrical solar collector. Applied Thermal Engineering 2014:73(1):1236-1243. https://doi.org/10.1016/j.applthermaleng.2014.07.067

[118] Selvakumar P., Somasundaram P., Thangavel P. Performance study on evacuated tube solar collector using therminol D-12 as heat transfer fluid coupled with parabolic trough. Energy Conversion and Management 2014:85:505-510. https://doi.org/10.1016/j.enconman.2014.05.069

[119] Yousefi T., Shojaeizadeh E., Veysi F., Zinadini S. An experimental investigation on the effect of pH variation of MWCNT-H $2 \mathrm{O}$ nanofluid on the efficiency of a flat-plate solar collector. Solar Energy 2012:86(2):771-779. https://doi.org/10.1016/j.solener.2011.12.003.

[120] Yousefi T., Veisy F., Shojaeizadeh E., Zinadini S. An experimental investigation on the effect of $\mathrm{MWCNT}_{2} \mathrm{H}_{2} \mathrm{O}$ nanofluid on the efficiency of flat-plate solar collectors. Experimental Thermal and Fluid Science 2012:39:207-212. https://doi.org/10.1016/j.expthermflusci.2012.01.025

[121]Faizal M., Saidur R., Mekhilef S. Potential of size reduction of flat-plate solar collectors when applying MWCNT nanofluid. ICEE 2013, IOP Conference Series: Earth and Environmental Science 2013:16(1) https://doi.org/10.1088/1755-1315/16/1/012004

[122] Nasrin R., Alim M. A., Chamkha A. J. Effects of physical parameters on natural convection in a solar collector filled with nanofluid. Heat Transfer-Asian Research 2013:42(1):73-88. https://doi.org/10.1002/hti.21026

[123] Tiwari A. K., Ghosh P., Sarkar J. Solar water heating using nanofluids - a comprehensive overview and environmental impact analysis. International Journal of Emerging Technology and Advanced Engineering 2013:3(9001):221-224.

[124] Kasaeian M. S. A. B., Sokhansefat T., Abbaspour M. J. Numerical Study of Heat Transfer Enhancement by using $\mathrm{Al}_{2} \mathrm{O}_{3}$ /Synthetic Oil Nanofluid in a Parabolic Trough Collector Tube. World Academy of Science, Engineering and Technology 2014:69:1154-1159.

[125] Tyagi H., Phelan P., Prasher R. Predicted Efficiency of a Low-Temperature Nanofluid-Based Direct Absorption Solar Collector. Journal of Solar Energy Engineering 2009:131(4):041004. https://doi.org/10.1115/1.3197562

[126]Elmir M., Mehdaoui R., Mojtabi A. Numerical simulation of cooling a solar cell by forced convection in the presence of a nanofluid. Energy Procedia 2012:18:594-603. https://doi.org/10.1016/j.egypro.2012.05.072.

[127]Liu Z. H., Hu R. L., Lu L., Zhao F., Xiao H. S. Thermal performance of an open thermosyphon using nanofluid for evacuated tubular high temperature air solar collector. Energy Conversion and Management 2013:73:135-143. https://doi.org/10.1016/j.enconman.2013.04.010

[128]De Risi A., Milanese M., Laforgia D. Modelling and optimization of transparent parabolic trough collector based on gas-phase nanofluids. Renewable Energy 2013:58:134-139. https://doi.org/10.1016/j.renene.2013.03.014

[129]Cui Y., Zhu Q. Study of photovoltaic/thermal systems with MgO-water nanofluids flowing over silicon solar cells. Asia-Pacific Power and Energy Engineering Conference, 2012.

[130]Li Y., Xie H. Q., Yu W., Li J. Investigation on Heat Transfer Performances of Nanofluids in Solar Collector. Mater. Sci. Forum 2011:694:33-36. https://doi.org/10.4028/www.scientific.net/msf.694.33

[131] Chougule S. S., Pise A. T., Madane P. A. Performance of nanofluid-charged solar water heater by solar tracking system. IEEE-international conference on advances in engineering, science and management ICAESM 2012, 2012.

[132] Otanicar T. P., Phelan P. E., Prasher R. S., Rosengarten G., Taylor R. A. Nanofluid-based direct absorption solar collector. Journal of Renewable and Sustainable Energy 2010:2(3):033102. https://doi.org/10.1063/1.3429737

[133] Taylor R. A. et al. Applicability of nanofluids in high flux solar collectors. Journal of Renewable and Sustainable Energy 3(2):023104. https://doi.org/10.1063/1.3571565

[134]Lenert A., Wang E. N. Optimization of nanofluid volumetric receivers for solar thermal energy conversion. Solar Energy 2012:86(1):253-265. https://doi.org/10.1016/j.solener.2011.09.029

[135] Taylor R. A., Otanicar T., Rosengarten G. Nanofluid-based optical filter optimization for PV/T systems. Light: Science and Applications 2012:1(e34):1-7. https://doi.org/10.1038/1sa.2012.34 
[136] Taylor R. A., Phelan P. E., Otanicar T. P., Adrian R., Prasher R. Nanofluid optical property characterization: towards efficient direct absorption solar collectors. Nanoscale Research Letters 2011:6(1):1-11. https://doi.org/10.1186/1556$\underline{276 X-6-225}$
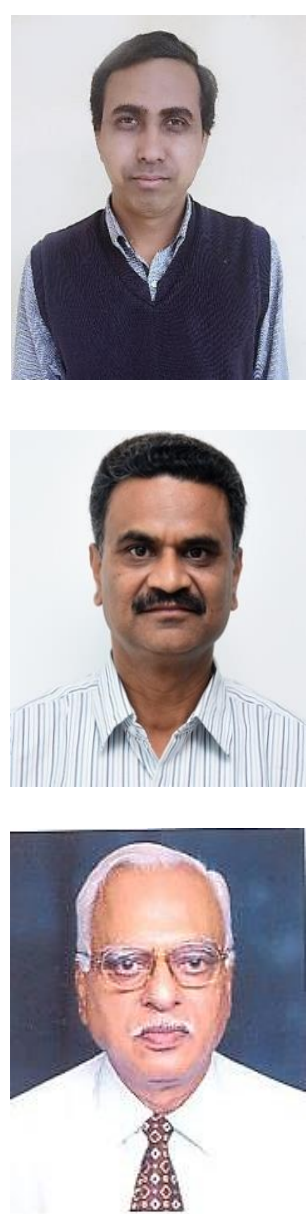

Mr. Vednath P. Kalbande is currently pursuing his doctoral degree from RTMNU Nagpur. He was earned master degree from VNIT, Nagpur in 2011 with a specialization in Heat Power Engineering. He is also currently working as an Assistant Professor in Mechanical Engineering Department of G H Raisoni College of Engineering, Nagpur. Mr. Vednath has eight years of teaching experience.

He won the IVCA Top Innovator award from CII/DST/AICTE in i3 Innovation National Fair 2015 for his project. He guided 50 plus undergraduate students for the projects. Mr. Vednath is strongly involved in research based on solar, thermal and nanofluid. He attended and presented his research work at many international and national conferences. He also published two papers in a reputed journal such as Energy Storage of Wiley publications.

Email: vednathkalbande@gmail.com v.kalbande@ raisoni.net

ORCID iD: https://orcid.org/0000-0002-7862-0563

Dr. Pramod V. Walke obtained Ph.D. degree in Mechanical Engineering from RTM, Nagpur University; Nagpur in 2011. He is presently working as a Professor in Mechanical Engineering at $\mathrm{G} \mathrm{H}$ Raisoni College of Engineering, Nagpur. He has teaching and administrative experience of over 25 years and has Dean IQAC. He has been teaching several subjects in thermal engineering and has contributed a number of research papers to technical journals and conferences and has received the grant of Rs. 32 Lacs from various Government agencies for research projects. His research interests include Internal Combustion Engine, solar Energy, wind energy etc. He is a member of ISTE, SESI and Combustion Institute. ORCID iD: https://orcid.org/0000-0002-5418-279X

Dr. V. M. Kriplani received the Ph.D. degree (Heat transfer) from R.T.M. Nagpur University, Nagpur (India) in 1997 and M. Tech (Thermal Engineering) from Indian Institute of Technology, Madras (India).

He worked as Lecturer, Assistant professor, Professor; Principal in Engineering Colleges. He has teaching and administrative experience of 52 years. He has contributed a number of research papers in International Journals and international conferences. Previous publications in journals such as Renewable and Sustainable Energy Reviews (Elsevier), Biofuels (Taylor \& Francis). His research interests in I. C. Engines, heat transfer, nanofluids, refrigeration and air-conditioning, solar energy, biodiesel. He is Fellow of Institution of Engineering (India), Life member, Solar Energy Society of India, Life Member, Indian Society of Heating, Refrigeration and Air-Conditioning Engineer (ISHRAE).

ORCID iD: https://orcid.org/0000-0001-7888-9290 